\title{
Shallow volcanic reservoirs and pathways beneath Aso caldera revealed using ambient seismic noise tomography
}

\author{
Yu-Chih Huang ${ }^{1 *}$, Takahiro Ohkura ${ }^{2}$, Tsuneomi Kagiyama $^{2,3}$, Shin Yoshikawa ${ }^{2}$ and Hiroyuki Inoue ${ }^{2}$
}

\begin{abstract}
Imaging the shallow velocity structures beneath Aso caldera is necessary to further understand volcanism at the volcano and in the region. The network for monitoring Aso volcano has been progressively renewed and upgraded with denser and more modern instruments. We used approximately 4 years of seismic data recorded by a network of 25 seismic stations to image S-wave velocity (Vs) structures beneath Aso caldera with seismic noise interferometry. We calculated daily cross-correlation functions (CCFs) of broadband and short-period station pairs separately and then stacked CCFs monthly, to obtain the time-domain empirical Green's functions and corresponding Rayleigh-wave phase-velocity dispersion curves. Finally, we constructed 1-5-s phase-velocity maps interpolated from nodes spaced $0.05^{\circ}$ grid. The maps allow investigating crustal Vs structures between the surface and a depth of $6 \mathrm{~km}$, likely related to shallow volcanic reservoirs and pathways. High velocities are found within the first kilometer of the crust beneath post-caldera central cones. Low velocities in the center of the post-caldera central cones extend from the surface to a depth of 1-2.5 km; we infer that the anomalies mark shallow hydrothermal reservoirs likely replenished by precipitation and hydrographic networks. The prevalence of high velocities below $3 \mathrm{~km}$ can be considered as consolidated igneous rock. Low-velocity anomalies identified at depths of 5-6 km beneath the post-caldera central cones could be a manifestation of magma accumulation. The low-velocity belts situated at $2.5-5 \mathrm{~km}$ depths are likely pathways for the transfer of hydrothermal fluids, volcanic gases, or melting magma to the surface. The northern part of the caldera shows relevant lateral velocity variations, with low velocities and high velocities predominant in the east and west, respectively. Other low-Vs anomalies appear near the surface to the west and northwest of Aso caldera.
\end{abstract}

Keywords: Ambient seismic noise, S-wave velocity structure, Aso caldera, Shallow crust, Volcanic reservoirs and pathways

\section{Introduction}

Volcanic activity is generally associated with magmatic-hydrothermal systems, which can be investigated through imaging seismic velocity structures. In particular, S-wave velocity $(V \mathrm{~s})$ structures are generally correlated with hydrothermal fluid or magma distributions. In the early Twenty-first century, monumental insights

\footnotetext{
*Correspondence: huangyc@ncree.narl.org.tw

${ }^{1}$ National Center for Research on Earthquake Engineering, National Applied Research Laboratories, No. 200, Section 3 Xinhai Rd, Taipei 10668, Taiwan
Full list of author information is available at the end of the article

Full list of author information is available at the end of the article Yu-Chih Huang (at 2nd affiliation between January, 2015 and December, 2017).
}

have been gleaned from deriving information regarding substantial velocity structures from ambient seismic noise in various parts of the world (e.g., Shapiro et al. 2005; Lin et al. 2007; Yang et al. 2007; Bensen et al. 2008; Zheng et al. 2008; Nishida et al. 2009; Saygin and Kennett 2010; Kao et al. 2013; Goutorbe et al. 2015). Velocity structures can demonstrably be retrieved by cross-correlating ambient seismic noise signals with continuous and simultaneous recordings of seismic networks (e.g., Weaver 2005). The aperture and density of seismic stations have positive correlations with the depth and lateral resolution of the obtained velocity structures. Such investigations on active volcanoes have discovered magma chambers, hydrothermal reservoirs, 
and temporal velocity variations related to volcanic activity. Examples include Asama and Naruko/Onikobe volcanic area in Japan (Nagaoka et al. 2012; Tamura and Okada 2016), Piton de la Fournaise volcano on La Réunion island (Brenguier et al. 2007), volcanic arc of Southern Peru (Ma et al. 2013), Colima Volcanic Complex in Mexico (Escudero and Bandy 2017), and Tatun Volcano Group in Taiwan (Huang et al. 2017).

Aso volcano is situated at approximately the center of Kyushu and is one of the most active volcanoes in Japan (Fig. 1a). Four caldera-forming eruptions have occurred, and Aso-4 ( $\sim 89 \mathrm{ka})$ formed the existing caldera, which has an approximate size of $18 \mathrm{~km}$ by $25 \mathrm{~km}$ in the E-W and $\mathrm{N}-\mathrm{S}$ directions, respectively (e.g., Machida and Arai 1983; Ono and Watanabe 1985; Fujii et al. 2001). Since Aso-4, eruptions have been concentrated in the postcaldera central cones. More than 17 cones were created on the surface, e.g., Takadake, Nakadake, Kishimadake, Komezuka and Kusasenrigahama (Fig. 1b). The largest pyroclastic eruption occurred at the Kusasenrigahama Volcano at approximately $30 \mathrm{ka}$, and the volcanic deposits have been well studied (e.g., Miyabuchi et al. 2003; Miyabuchi 2009, 2011). Fumaroles, hot springs, and surface geothermal activity can be observed on the southwestern flanks of the post-caldera central cones.

Aso volcano becomes active at intervals of approximately 10-20 years (e.g., Sudo 2001), and Nakadake is the most active cone within the historic times. The total craterous area of Nakadake comprises seven craters that are roughly aligned in a N-S direction (Japan Meteorological Agency; JMA 2013), and volcanic eruptions have been more frequently observed in the northernmost crater (i.e., the first crater of Nakadake). The major type of post-caldera eruption for Aso volcano is strombolian. Mud, phreatic, and phreatomagmatic eruptions have occasionally occurred when the volcano has been particularly active or unstable (Ikebe et al. 2008). Recently, magmatic eruptions occurred from November 2014 to May 2015, followed by two major phreatomagmatic eruptions occurred on September 14, 2015, and October 8, 2016 (e.g., Miyabuchi et al. 2018; Ishii et al. 2018).

Long-period tremors (LPTs) with dominant periods of 10-15 s have been observed originating from Aso volcano (Kawakatsu et al. 1994; Kaneshima et al. 1996; Kawakatsu et al. 2000; Legrand et al. 2000). LPTs were located at a depth of 1-1.5 km beneath the crater and were considered to be from a hydrothermal reservoir rather than a magma chamber, with the reservoir containing cracks filled with volcanic fluids and gases that continuously resonate and generate the LPTs. The existence of this hydrothermal reservoir underneath the crater is also considered to be related to the occurrence of phreatic eruptions.
Investigations of the volcanism and magma plumbing system of Aso volcano in the shallow crust have primarily been conducted through various methods. Kanda et al. (2008) deployed magnetotelluric (MT) surveys to determine the electrical structures down to a depth of approximately $1 \mathrm{~km}$ and revealed a strongly conductive zone at several hundred meters depth beneath the first crater of Nakadake and surrounding area. Hata et al. (2016) concluded three-dimensional (3-D) model of electrical resistivity and identified a magma pathway in the upper crust beneath the caldera. On the other hand, findings regarding seismic velocity and attenuation structure (Sudo 1991; Sudo and Kong 2001) have indicated that the magma chamber has a roughly spherical shape centered under Eboshidake at a depth of $6-10 \mathrm{~km}$ and exhibits low $V \mathrm{~s}$, a high $\mathrm{P}$-wave velocity $(V \mathrm{p})$-to- $V \mathrm{~s}$ ratio, and high attenuation (low $Q$ value). Yamamoto et al. (1999) detected a crack-like conduit along the chain of craters that dipped toward the magma chamber. They suggested that volcanic gases, hydrothermal fluids, and pyroclastic fragments were being discharged along the conduit. Tsutsui et al. (2003) obtained 3-D Vp structures beneath the post-caldera central cones form the seismic data of a controlled-source experiment. Tsutsui and Sudo (2004) further detected seismic reflection voids, indicating high-temperature areas beneath the crater at a depth of $1.5-3.5 \mathrm{~km}$ and to the west of the crater at a depth of $3.5-7 \mathrm{~km}$. Additionally, Abe et al. $(2010,2017)$ determined a deeper low- $V$ s zone near the Conrad discontinuity by conducting receiver function analyses.

The aforementioned studies merely focused on either detailed images of subsurface structures under the postcaldera central cones or large-scale crustal features beneath Aso caldera. The information is lacking regarding the detailed shallow crustal Vs structures to image volcanic reservoirs and pathways. Since the basic theorem of ambient seismic noise has been supported and is routinely used worldwide to investigate subsurface velocity structures, the methodology has not been applied to Aso caldera. The network for monitoring Aso volcano has been progressively upgraded to involve the use of more modern instruments. Continual improvement has also been observed in station density and the types of observations made. In this study, we used a seismic monitoring network containing broadband (BB) and shortperiod (SP) stations to report information regarding the ambient seismic noise. We constructed 1-5-s phasevelocity maps interpolated from nodes spaced $0.05^{\circ}$ grid. The maps allow investigating crustal $V \mathrm{~s}$ structures between the surface and a depth of $6 \mathrm{~km}$. Finally, we captured images of shallow volcanic reservoirs and pathways beneath Aso caldera and compared them with the results of other studies. 


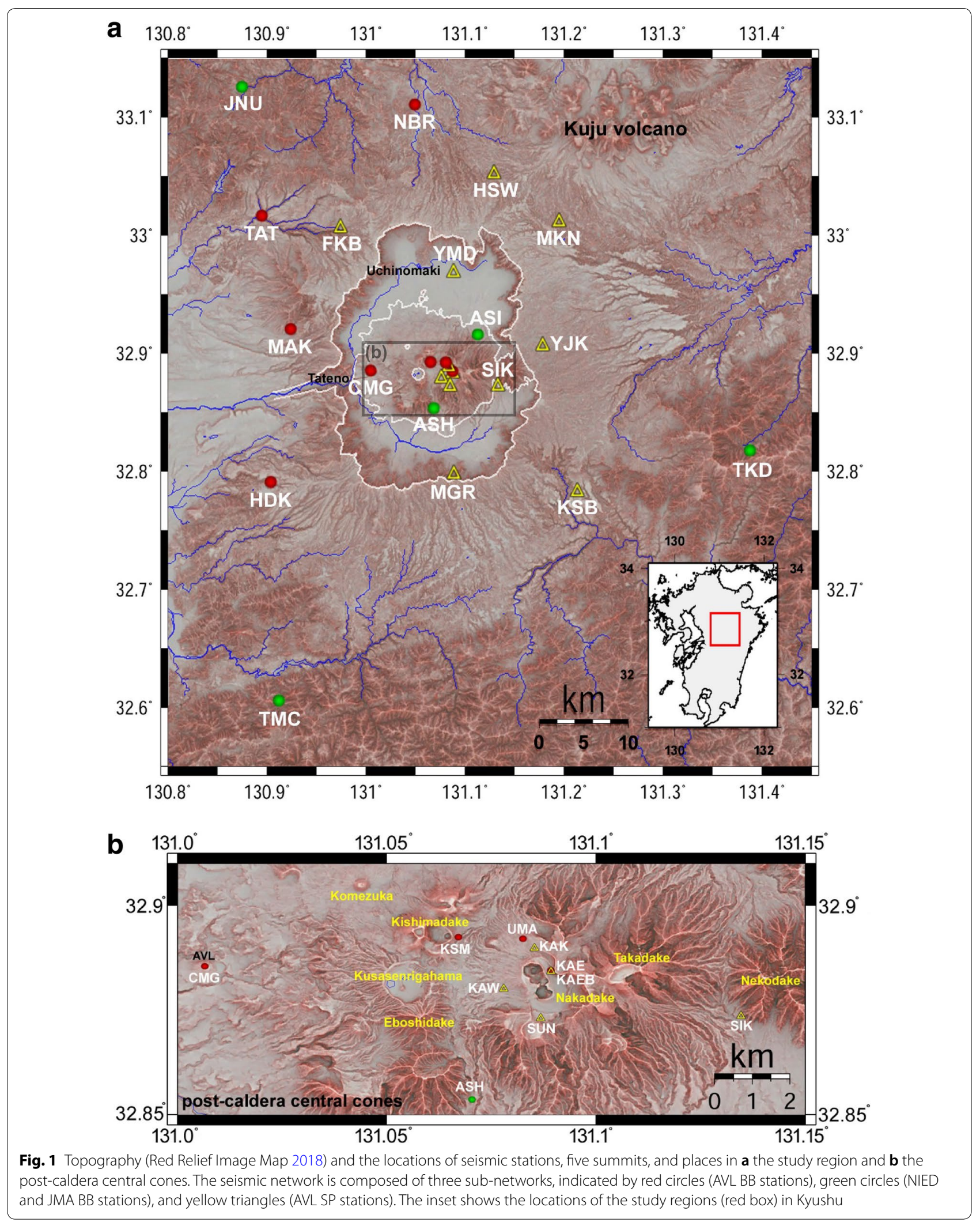




\section{Data and methods}

\section{Seismic network and data}

The seismic monitoring network operated and maintained by the Aso Volcanological Laboratory (AVL) has been gradually updated with denser and more modern seismometers. Because SP seismometers have been replaced with $\mathrm{BB}$ seismometers at some stations, $8 \mathrm{BB}$ (CMG-40T or STS-2; red circles in Fig. 1) and $12 \mathrm{SP}$ (PK-110 or L-4C-3D; yellow triangles in Fig. 1) sensors were employed. A further 5 BB seismic stations equipped with STS-2 seismometers (green circles in Fig. 1)-the JNU station of the JMA and 4 stations operated by the National Research Institute for Earth Science and Disaster Resilience (NIED; V-net: ASH and ASI; F-net: TKD and TMC)-were also selected to increase station and path density. In total, 25 seismic stations (corresponding to $13 \mathrm{BB}$ and $12 \mathrm{SP}$ seismometers) comprised the network (Fig. 1). Interstation distances were much shorter ( 1 to $2 \mathrm{~km})$ near the Nakadake crater than in the area surrounding Aso caldera ( 10 to $20 \mathrm{~km})$. The seismic data set covered a time period of approximately 4 years, from November 1, 2009, to September 20, 2013. The selected period ended approximately 1 year before the most recent volcanic eruptions that began on November 25, 2014.

\section{Data processing}

Figure 2 presents the data analysis procedures that were used, which were primarily based on those of Yao et al. (2006) and Huang et al. (2010, 2017). Files of raw seismic data were produced in the WIN format (WIN System 2017), and the data had a duration of $1 \mathrm{~min}$ and a sampling rate of 100 or $200 \mathrm{~Hz}$. First, we converted the raw daily vertical component data from the WIN to the SAC (Seismic Analysis Code; SAC Manual 2017) format. SAC2000 (Goldstein et al. 2003) was then employed to lower the sampling rate to $20 \mathrm{~Hz}$ and perform baseline corrections of the seismograms for the purpose of removing the mean and trend. Data quality and timing accuracy were preliminarily assessed so that data with suspected timing problems or spurious signals could be discarded. After data preparation, the daily cross-correlation function (CCF) was calculated for each station pair.

Daily CCFs were derived using one-bit cross-correlation and spectral whitening for enhancing the spectral energy of ambient seismic noise; hence, the obtained CCFs exhibit a high signal-to-noise ratio (SNR). The basic concepts of these two methods have been verified and regularly utilized for research on ambient seismic noise (e.g., Larose et al. 2004; Shapiro and Campillo 2004; Yao et al. 2006; Yang et al. 2007; Yao et al. 2009; Cupillard and Capdeville 2010; Cupillard et al. 2011). The daily CCFs of

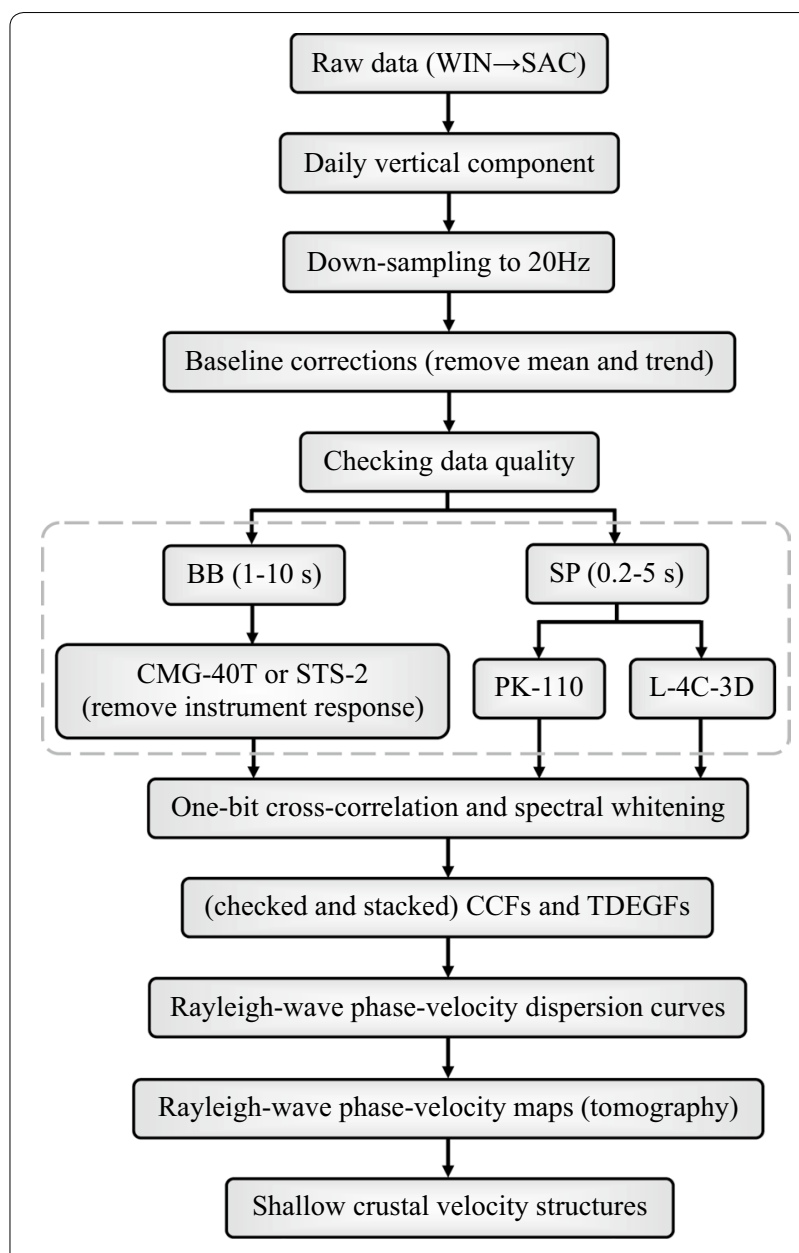

Fig. 2 Data processing of ambient seismic noise analysis

the BB and SP station pairs were obtained separately and then stacked according to the month to retain coherent signals. Monthly CCFs were then further compared and stacked to acquire post-processing time-domain empirical Green's functions (TDEGFs) and Rayleigh-wave phase-velocity dispersion curves.

The TDEGF was further derived from the time-derivative of the CCF (e.g., Sabra et al. 2005a, b; Yao et al. 2006; Lin et al. 2008). Regardless of whether the TDEGFs were symmetric or asymmetric (e.g., Sabra et al. 2005b; Stehly et al. 2006), we superimposed the components of positive and negative lag times onto the TDEGFs to enhance the coherent signals, as has been done in other studies (e.g., Lin et al. 2007; Yang et al. 2007). This approach prevents the artificial selection of positive or negative lag times and minimizes the possible effects of uneven seismic noise source distributions.

The phase image analysis and far-field approximation methods were employed to measure the Rayleigh-wave phase-velocity dispersion curves for each station pair (Yao et al. 2006). Phase image analysis enables selection 
of an appropriate dispersion curve from the peaks that occur at different periods in the TDEGF. To ensure that the surface waves were fully generated between the station pairs, we required that interstation distances be at least twice the wavelength of the propagating surface waves. Thus, the maximum period of the measured Rayleigh-wave phase-velocity dispersion curve in this study was closely correlated to interstation distance.

Before constructing phase-velocity maps, checkerboard resolution test (CRT) models at different scales were used to assess the lateral resolution of the obtained phase velocities. Subsequently, we applied the tomographic method proposed by Yao et al. (2006) using a generalized least-squares algorithm for constructing phasevelocity maps for periods of $1-5 \mathrm{~s}$. The shallow crustal $V$ s structures were then constructed from the obtained phase-velocity maps. At every grid point inside the study regions, Rayleigh-wave phase-velocity dispersion curves were extracted from the obtained phase-velocity maps. The SURF program (Herrmann 1987, 2013) was then employed to derive 1-D Vs structures. Finally, possible candidates for volcanic reservoirs and pathways underneath Aso caldera were identified from the shallow crustal $V \mathrm{~s}$ structure reconstructions.

\section{Cross-correlation functions}

The BB stations had two types of seismometers, and the instrument responses (poles and zeros) of which had to be removed before CCFs could be calculated. The SP stations also possessed two types of seismometers, but the instrument responses of the PK-110 units were unobtainable. Thus, our only option was to separately calculate the SP CCFs for the two unit types without necessarily eliminating instrument responses (Fig. 2). Daily CCFs were calculated with a 100-s lag time in both the 1-10-s period band for the BB station pairs and 0.2-5-s period band for the SP station pairs. Figure 3 presents examples of monthly CCFs (i.e., stacked daily CCFs) for the BB station pair HDK-TKD and SP station pair MGR-SUN. The results reveal numerous similarities between monthly CCFs during the study period.

Although conspicuously problematic data had already been removed before the calculation of the CCFs, a low SNR or temporary CCF variation was observed in some station pairs. Consequently, we eliminated the daily CCFs that exhibited considerable problems or time shifts and then restacked the monthly CCFs to achieve higher SNRs. Figure 4 presents three examples of problematic monthly CCFs (color heatmap) with their total and annual averages (black lines). The low SNR for CMG-UMA and the periodic signals for FKB-KSB are suspected to be due to instrumental problems. Temporal variation for JNUTKD appears to be a shift in the same direction at both positive and negative lags rather than symmetric shifts in both directions, and it could be attributed to temporary timing-accuracy failures (e.g., Stehly et al. 2007; SensSchönfelder 2008; Huang et al. 2017). Although simple velocity change is expected to generate symmetric shifts, complex variations in underground velocity could also explain the moving in the same direction (e.g., Sabra et al. 2006; Sens-Schönfelder and Wegler 2006; De Plaen et al. 2016). To minimize these problems, we use stacked monthly CCFs for 4 years in the following analyses.

The stacked monthly CCFs were derived from 74 BB and 31 SP station pairs to further obtain Rayleigh-wave phasevelocity dispersion curves. Figure 5 displays the stacked monthly CCFs versus the interstation distance. Figure $5 \mathrm{a}$ reveals that the Rayleigh-wave signals of the $\mathrm{BB}$ station pairs mainly propagated with an apparent velocity between 1.3 and $3.8 \mathrm{~km} / \mathrm{s}$. However, Fig. 5b shows no obvious velocity window for the SP station pairs. Possible reasons for this are that (1) the SP stations were heterogeneously distributed in the area surrounding the Nakadake crater and the eastern portion of Aso caldera (Fig. 1); and (2) the analyzed period bands of the SP CCFs were shorter, and ambient seismic signals are easily contaminated by human activities cannot fully propagate over long distances.

\section{Directionality of ambient seismic noise sources}

In theory, in an ideal situation, we would expect an isotropic distribution of ambient seismic noise sources to obtain time-symmetric CCFs and TDEGFs (e.g., Roux et al. 2005). However, in practice, most cases have yielded asymmetric results because of the uneven distribution of ambient seismic noise sources, which mainly correlated to microseisms generated by ocean wave interactions with the seafloor or coastlines (e.g., Sabra et al. 2005b; Yao et al. 2006; Stehly et al. 2006; Lin et al. 2007; Huang et al. 2010). In Aso volcano, another consideration is LPTs, with dominant periods of $10-15 \mathrm{~s}$, which have been observed as mentioned in the previous section. Consequently, we first attempted to understand the possible directionality of ambient seismic noise sources during the study periods.

We referred to studies conducted by Stehly et al. (2006) and Huang et al. (2010) to determine the major directions of ambient seismic energy propagating through our network using statistics of symmetry or asymmetry of the stacked monthly CCFs (Fig. 5), according to the orientations of station pairs. Every station pair constrained two opposite directions, and incident seismic energy was calculated based on the amplitudes of the positive and negative lag times of the CCFs. Nevertheless, we could only detect the directionality of ambient seismic noise sources rather than the exact locations from which the ambient seismic energy was being generated. We separated 


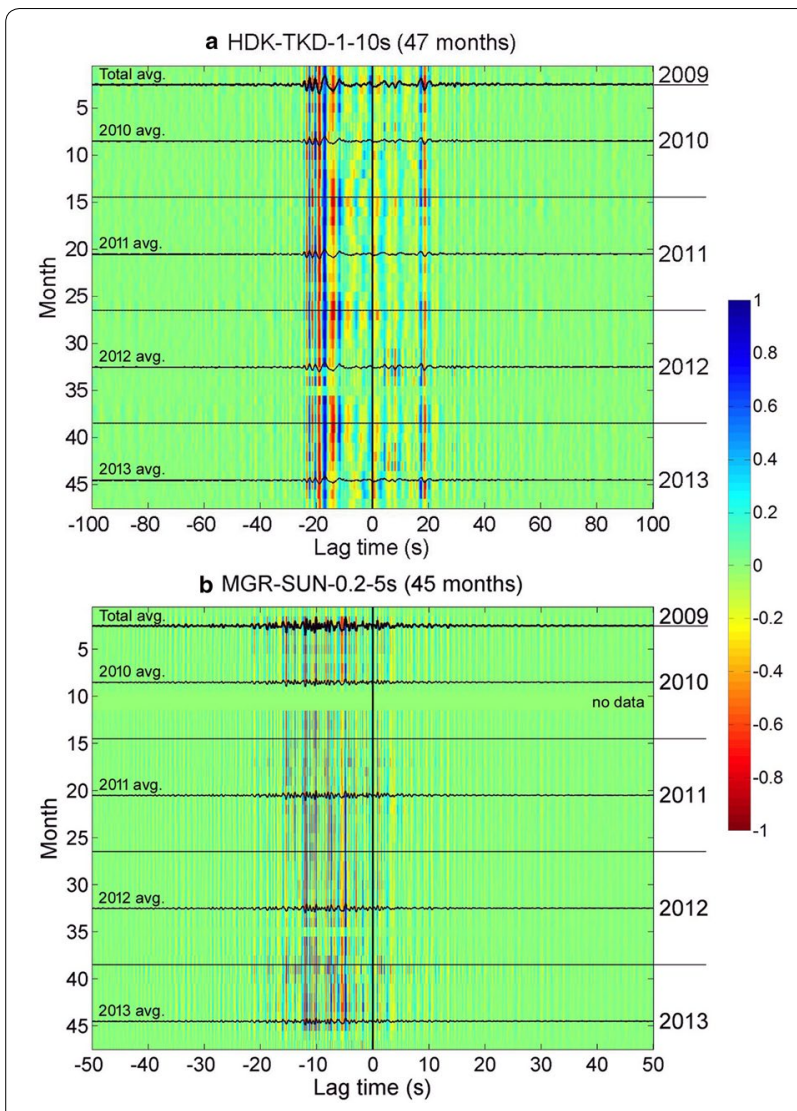

Fig. 3 Examples of monthly CCFs for a the BB station pair (HDK-TKD) with 100-s lag time in the 1-10-s period band and $\mathbf{b}$ the SP station pair (MGR-SUN) with 50-s lag time in the $0.2-5$-s period band. Color heatmap correlates to the normalized amplitude of CCFs. Black lines indicate the total and annual average of the monthly CCFs. The data length (in months) is displayed in parentheses

azimuth into 36 sectors, each at $10^{\circ}$, and specified that the signal be within the velocity window of $1.3-3.8 \mathrm{~km} / \mathrm{s}$ (Fig. 5a) and that noise be within the velocity window of $0.6-0.8 \mathrm{~km} / \mathrm{s}$ to calculate SNR.

Figure 6a displays the azimuthal dependence of the normalized amplitudes of stacked monthly CCFs for BB, SP, and integrated BB and SP station pairs in Fig. 5, with $\mathrm{SNR} \geq 5$. Because SP stations were heterogeneously distributed, the detected incident seismic energy was restricted according to the orientations of the station pairs. Figure 6a presents the general, wide azimuthal coverage and relatively isotropic distribution of ambient seismic noise sources during our study periods in Aso caldera, especially for the BB station pairs. The existence of high-SNR station pairs in various directions supports the dominance of a homogeneously distributed ambient seismic noise source in these station pairs, and we use these stations in the main analyses.

We wanted to further confirm that ambient seismic noise sources primarily originated from outside our seismic network, rather than being dominated by LPTs generated by Aso volcano itself. Therefore, we took JNU and TKD as examples (Fig. 1a; two BB stations at the border of the seismic network) to exhibit the stacked monthly CCFs versus interstation distance with the associated station pairs. Figure $6 \mathrm{~b}$ demonstrates the fairly timesymmetric CCFs, and the positive lag time represents ambient seismic energy partially moving in the direction from JNU and TKD toward the other stations (sources outside of Aso caldera), which implies that the LPTs did not significantly dominate ambient seismic noise sources during our study periods. Possible explanations for this result include the following: (1) our seismic data set spans approximately 4 years with relatively calm volcanic activity and hence effects related to temporary volcanic activity could be minimized with long-term stacking to derive relatively stable CCFs and velocity structures, and (2) the dominant frequency of observed LPTs in Aso volcano was between 10 and $15 \mathrm{~s}$, which are longer periods than our obtained CCFs for the station pairs of SP $(0.2-5 \mathrm{~s})$ and BB (1-10 s).

\section{Rayleigh-wave dispersion analyses and velocity structures}

Phase-velocity dispersion curves

The difference in elevation between station pairs directly correlated to the measurement of the Rayleighwave phase-velocity dispersion curve. We specified the linear distance $\left(d_{\mathrm{L}}\right)$ between two seismic stations as $d_{\mathrm{L}}=\sqrt{d_{\mathrm{H}}^{2}+d_{\mathrm{V}}^{2}}$, where $d_{\mathrm{H}}$ is the (horizontal) intersta-

tion distance and $d_{\mathrm{V}}$ is the (vertical) elevation difference. The maximal $d_{\mathrm{V}}$ among the station pairs was approximately $1000 \mathrm{~m}$ for KAEB-TMC (a BB station pair; see Fig. 1) with heights of $1270 \mathrm{~m}$ for KAEB and $285 \mathrm{~m}$ for TMC; nevertheless, $d_{\mathrm{H}}$ was $35 \mathrm{~km}$ and the discrepancy in distance $\left(d_{\mathrm{L}}-d_{\mathrm{H}}\right)$ was only $14 \mathrm{~m}$ $\left(\sim 0.04 \%\right.$ of $\left.\mathrm{d}_{\mathrm{L}}\right)$. The maximal distance discrepancy was $46 \mathrm{~m}\left(\sim 1 \%\right.$ of $\left.d_{\mathrm{L}}\right)$ for ASI-KAEB (a BB station pair) on the post-caldera central cones; however, because $d_{\mathrm{H}}=4.2 \mathrm{~km}$, the distance was too short to measure phase velocities based on the far-field approximation. Overall, 64 BB and $31 \mathrm{SP}$ station pairs were used to 


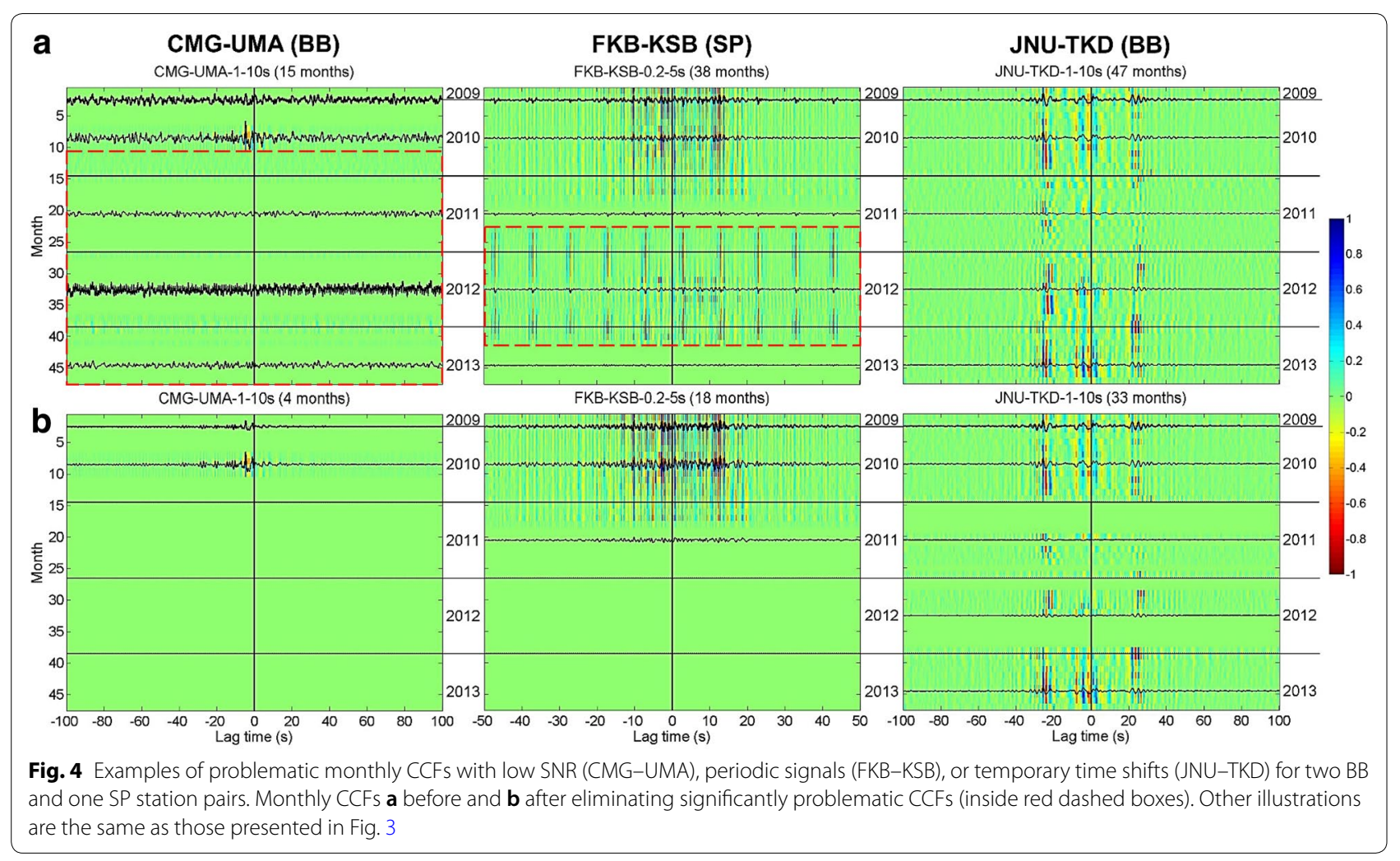

derive Rayleigh-wave phase-velocity dispersion curves (Fig. 7). More than $60 \%$ of the station pairs had a distance discrepancy of less than $5 \mathrm{~m}$, that is, $<0.05 \%$ of $d_{\mathrm{L}}$. Accordingly, the possibility of bias related to elevation differences between station pairs was insignificant in our Rayleigh-wave phase-velocity measurements.

Figure 7 presents the measured Rayleigh-wave phasevelocity dispersion curves with averages and standard deviations for the $64 \mathrm{BB}$ station pairs in the 1-7-s period band (Fig. 7a) and 31 SP station pairs in the 0.25 -s period band (Fig. 7b). The average phase velocities for the SP station pairs exhibited large standard deviations and were relatively low compared with those for the $\mathrm{BB}$ station pairs. The difference in average phase velocities reached a maximum of $0.47 \mathrm{~km} / \mathrm{s}$ at $1 \mathrm{~s}$ and gradually decreased to a minimum of $0.05 \mathrm{~km} / \mathrm{s}$ at $4.3 \mathrm{~s}$. We integrated the results of the BB and SP station pairs (a total of 95 station pairs) for the $0.2-7$-s period band, as displayed in Fig. 7c. Figure $7 d$ presents the number of phase-velocity measurements for each period, with the most at $1.7 \mathrm{~s}$ and relatively high values in the $1-2-\mathrm{s}$ period band. To retain an adequate number of paths, further analysis focused on the 1-5-s period band with phase-velocity measurements between 29 (at $5 \mathrm{~s}$ ) and 88 (at $1.7 \mathrm{~s}$ ).

For a preliminary impression of the velocity distributions, we compared the obtained Rayleigh-wave phasevelocity dispersion curves, as illustrated in Fig. 8. The selected station pairs had similar interstation distances to enable sampling of velocity structures at equivalent depths. Figure 8 a presents the Rayleigh-wave phasevelocity dispersion curves for five $\mathrm{BB}$ station pairs transecting different portions of the study region with approximate interstation distances of $50 \mathrm{~km}$. Phase velocities were relatively high outside Aso caldera (NBR-TKD and TKD-TMC) and gradually decreased when approaching the post-caldera central cones (MAK-TKD), exhibiting a variance of approximately $0.5 \mathrm{~km} / \mathrm{s}$. Figure $8 \mathrm{~b}$ presents the dispersion curves for six station pairs, including BB and SP stations, with approximate interstation distances of $10 \mathrm{~km}$ across different parts of Aso caldera. High phase velocities characterized the east of the caldera (KSB-YJK) and the northwestern side of the caldera (FKB-YMD). By 


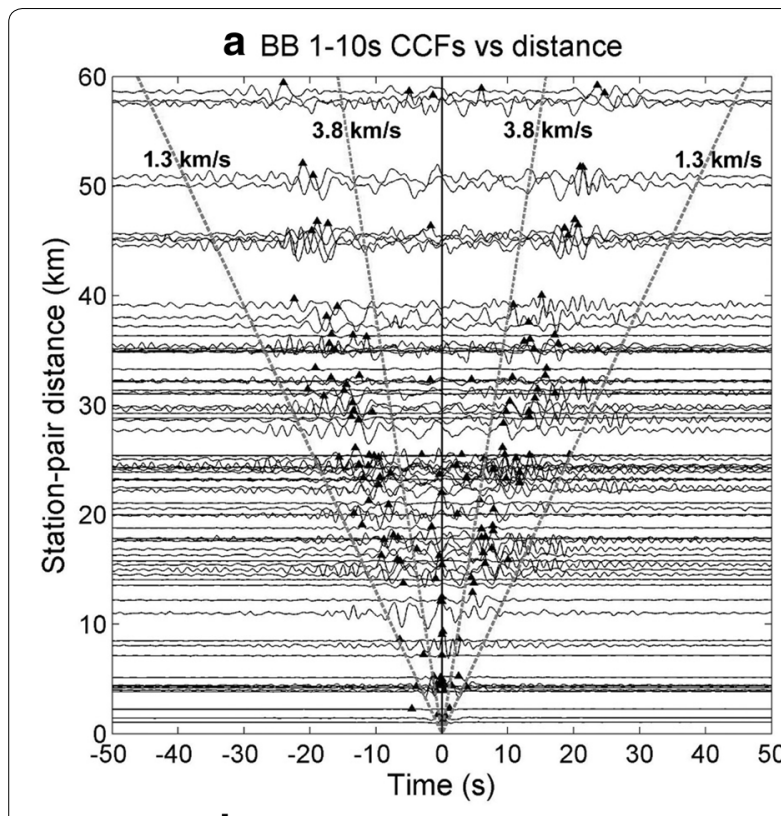

b SP $0.2-5 \mathrm{~s}$ CCFs vs distance

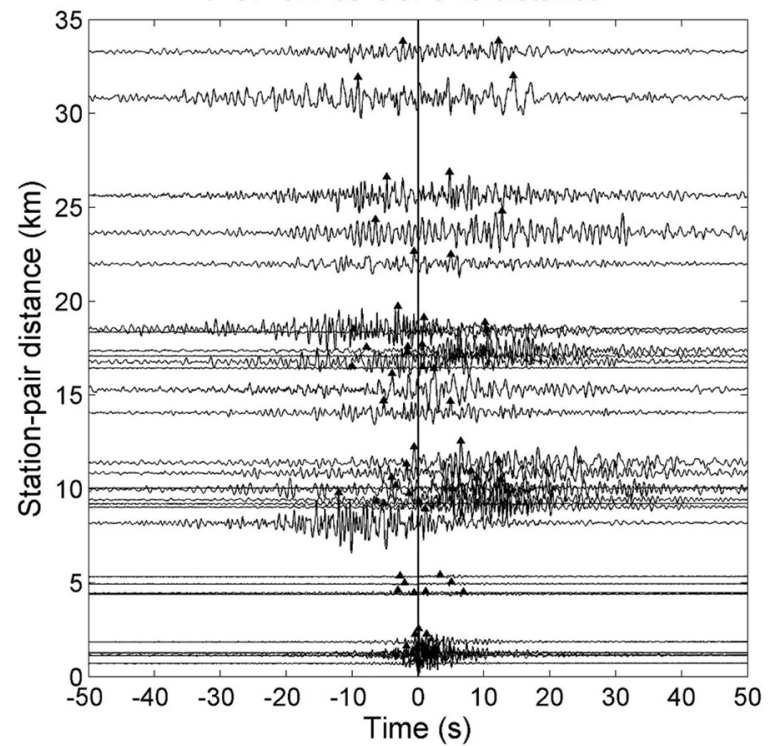

Fig. 5 Stacked monthly CCFs versus interstation distance for all station pairs: a 1-10-s BB station pairs demonstrate the propagation of main Rayleigh-wave signals with an apparent velocity window of $1.3-3.8 \mathrm{~km} / \mathrm{s}$ (gray dashed lines); b $0.2-5-\mathrm{s}$ SP station pairs demonstrate Rayleigh-wave signals without a distinct velocity window. Black triangles mark the maximum amplitude of CCFs on the positive-time and negative-time axes separately

contrast, low phase velocities prevailed in the post-caldera central cones (MAK-UMA and KAW-MGR) and on the northeastern side of the caldera (YJK-YMD).

\section{Path coverage and lateral resolution}

Numerous instances of path coverage and normalized relative path density of the phase-velocity measurements during four arbitrarily selected periods (i.e., 1.5, 2.5, 3.5, and $4.5 \mathrm{~s}$ ) are displayed in Fig. 9. Overall, $>80$ paths were observed at $1-2 \mathrm{~s}, \geq 20$ of which were contributed by SP station pairs (Fig. 7d). Hence, relatively high path densities are present near the densely covered Nakadake crater (Fig. 9a). Although the number of paths decreases substantially at periods $>2 \mathrm{~s}$, the path density gradually becomes more evenly distributed throughout the post-caldera central cones (Fig. 9b), inside the caldera, to the northwest of the caldera (Fig. 9c), and in most areas of the study region (Fig. 9d).

The input CRT models with three scales exhibited a velocity contrast of $1.5 \pm 0.2 \mathrm{~km} / \mathrm{s}$ for $0.025^{\circ}, 0.05^{\circ}$, and $0.125^{\circ}$ anomalies with $0.01^{\circ}, 0.02^{\circ}$, and $0.05^{\circ}$ grid spacing, respectively (Fig. 10). Figure 11 summarizes the recovery results gathered from these three CRT models for four different, arbitrarily selected periods. Figure 11a presents the recovery results yielded using the $0.025^{\circ} \mathrm{CRT}$ model for periods of 1.0, 1.3, 1.6 , and $1.9 \mathrm{~s}$. Superior recoveries were initially concentrated near the Nakadake crater at $1.0 \mathrm{~s}$ and gradually reached their greatest extent over the post-caldera central cones at $1.9 \mathrm{~s}$. Figure $11 \mathrm{~b}$ presents the recovery results obtained using the $0.05^{\circ}$ model for periods of $1.5,2.0,2.5$, and $3.0 \mathrm{~s}$, indicating excellent recovery across most of Aso caldera. Finally, Fig. 11c displays the recovery results obtained using the $0.125^{\circ}$ model for periods of 2.0, 3.0, 4.0, and $5.0 \mathrm{~s}$, indicating that, apart from some margins, the entire study region was recovered.

Generally speaking, the lateral resolution of our Rayleigh-wave phase-velocity measurements could resolve the $0.025^{\circ}$ anomaly in the neighboring Nakadake crater for periods of approximately $1.0 \mathrm{~s}$, as well as $0.025^{\circ}$ anomalies in the post-caldera central cones for periods of $1.3-1.9 \mathrm{~s}$. For Aso caldera, the $0.05^{\circ}$ anomaly could be recovered for periods of 2.0-3.0 s. Over all except the northern, southern, and eastern margins of the study region, the $0.125^{\circ}$ anomaly could be recovered for periods of 3.0-5.0 s. The results obtained regarding path coverage and lateral resolution were used to construct phase-velocity maps for the $1-5$-s period band.

\section{Phase-velocity maps}

Based on the favorable good recovery results obtained using the $0.125^{\circ} \mathrm{CRT}$ model with $0.05^{\circ}$ grid spacing (Figs. 10c and 11c) for most of the study regions, we 


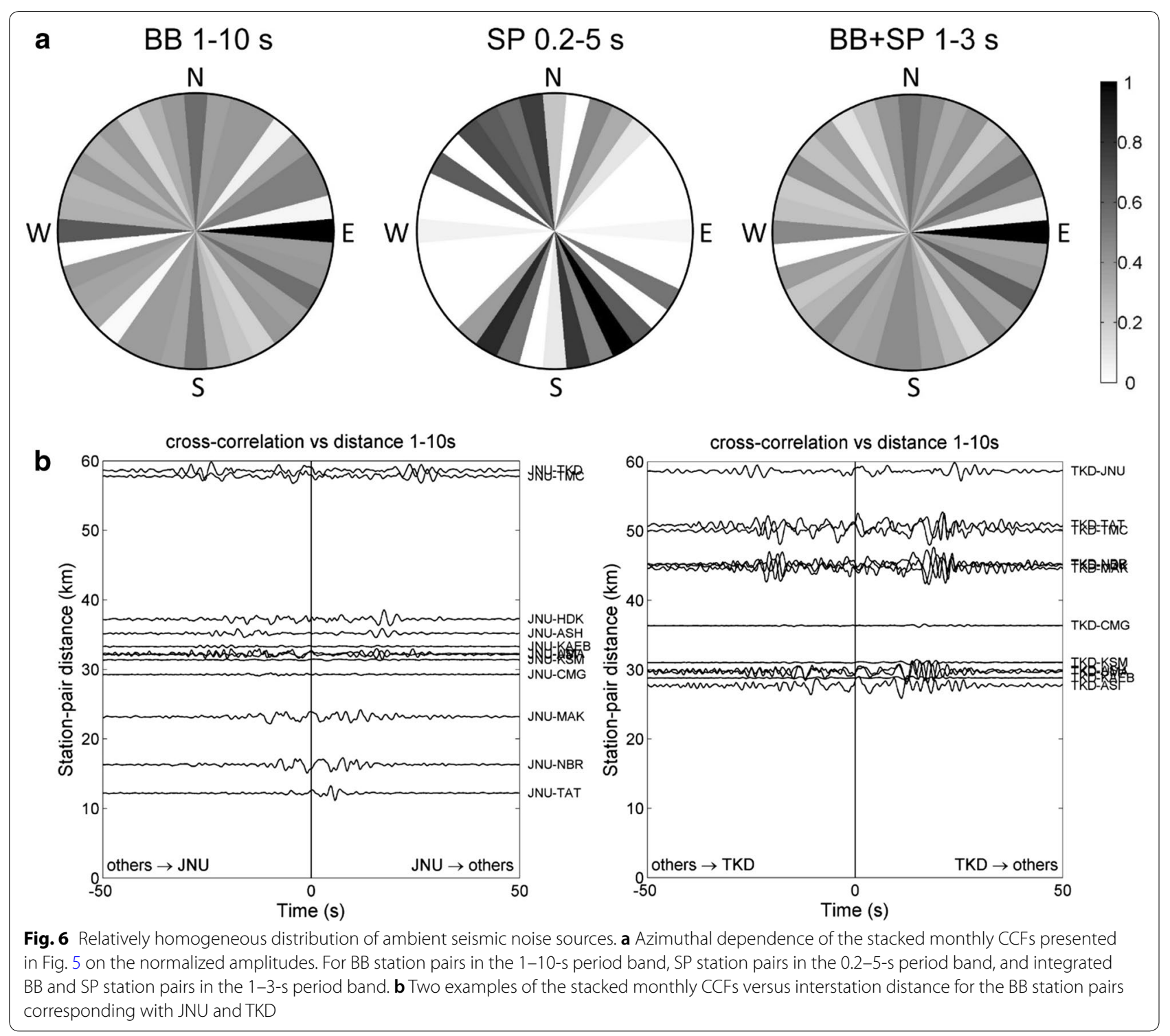

retained $0.05^{\circ}$ grid spacing for construction of phasevelocity distributions in the region $130.8-131.45^{\circ} \mathrm{E}$ and $32.55-33.15^{\circ} \mathrm{N}$. This resulted in 14 grid points in the longitudinal direction and 13 grid points in the latitudinal direction. Figures 12 and 13 display the phase-velocity maps derived for six and nine arbitrarily selected periods with disparate and identical velocity ranges to reveal predominant velocity patterns. The velocity perturbation for short periods was comparatively large (e.g., $1.9 \mathrm{~km} / \mathrm{s}$ for $1.0 \mathrm{~s}$ and $1.3 \mathrm{~km} / \mathrm{s}$ for $5.0 \mathrm{~s}$ ), indicating that greater velocity discrepancies existed at shallow depths.
For large-scale features, low velocities were dominant in the northwest of Aso caldera and high velocities in the east and south. At periods $\geq 2.5 \mathrm{~s}$ (Figs. 12d-f and 13), low velocities were dominant in most of Aso caldera and were surrounded by high velocities. For relatively small-scale features, the northern part of the caldera exhibited lateral velocity variation, that is, low velocity predominated in the east and high velocity in the west (Figs. 12 and 13). At periods $\leq 1.5 \mathrm{~s}$ (Figs. 12a, b and 13), the post-caldera central cones were characterized by high velocities, but a 


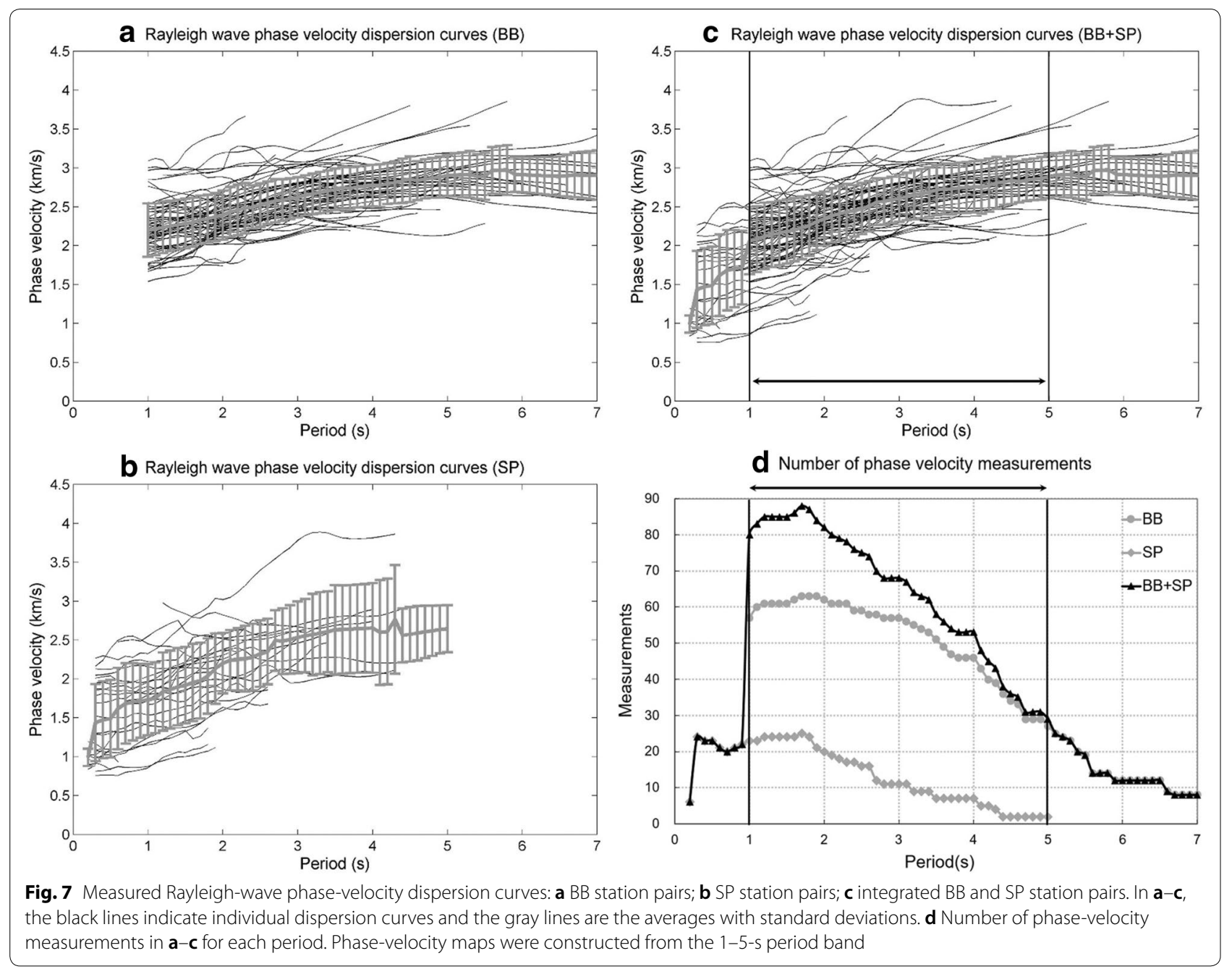

localized low-velocity anomaly was situated in the area surrounding Kusasenrigahama.

\section{Shallow crustal $V s$ structures}

We discretized the space with a layer thickness of $0.5 \mathrm{~km}$ for the uppermost $6 \mathrm{~km}$, and the deepest layer extends to the infinite depth homogeneously. As an initial model, we considered $V \mathrm{~s}=2.0 \mathrm{~km} / \mathrm{s}$ homogeneously for all grids. In accordance with the physical dispersion properties of surface waves (Kanamori and Anderson 1977), the other correlated parameters were selected to be $V \mathrm{p}=4.0 \mathrm{~km} / \mathrm{s}$, density $=2.3 \mathrm{~g} / \mathrm{cm}^{3}$, and Poisson's ratio $=0.28$. Although the investigated $V \mathrm{~s}$ structures might be affected by different initial models, the final $V$ s structures obtained were similar, with discrepancies $<1 \%$ (Huang et al. 2014, 2017).
Figure 14 displays four 6-km-deep $V$ s profiles obtained at different locations across Aso caldera. Figures 14a and b display two profiles transecting near the Nakadake crater in the latitudinal and longitudinal directions. The post-caldera central cones were characterized by high velocities $(V \mathrm{~s}>3 \mathrm{~km} / \mathrm{s}, \mathrm{H} 1)$ at surface depths of $1 \mathrm{~km}$ and were surrounded by low velocities $(V \mathrm{~s}<2 \mathrm{~km} / \mathrm{s}, \mathrm{L} 1)$ from the caldera surfaces to a depth of approximately $2.5 \mathrm{~km}$. High velocities $(V \mathrm{~s}>3 \mathrm{~km} / \mathrm{s}, \mathrm{H} 2)$ prevailed below $3 \mathrm{~km}$, but a remarkably low velocity $(V \mathrm{~s}<2 \mathrm{~km} / \mathrm{s}, \mathrm{L} 2)$ was discovered at a depth of 5-6 km beneath the post-caldera central cones. Between L1 and L2 were some interconnected low-velocity belts $(V \mathrm{~s}<3 \mathrm{~km} / \mathrm{s}, \mathrm{L} 3)$.

Figure 14c presents the profile transecting the northern part of the caldera in a latitudinal orientation. Considerable variations in lateral velocity were obtained beneath 


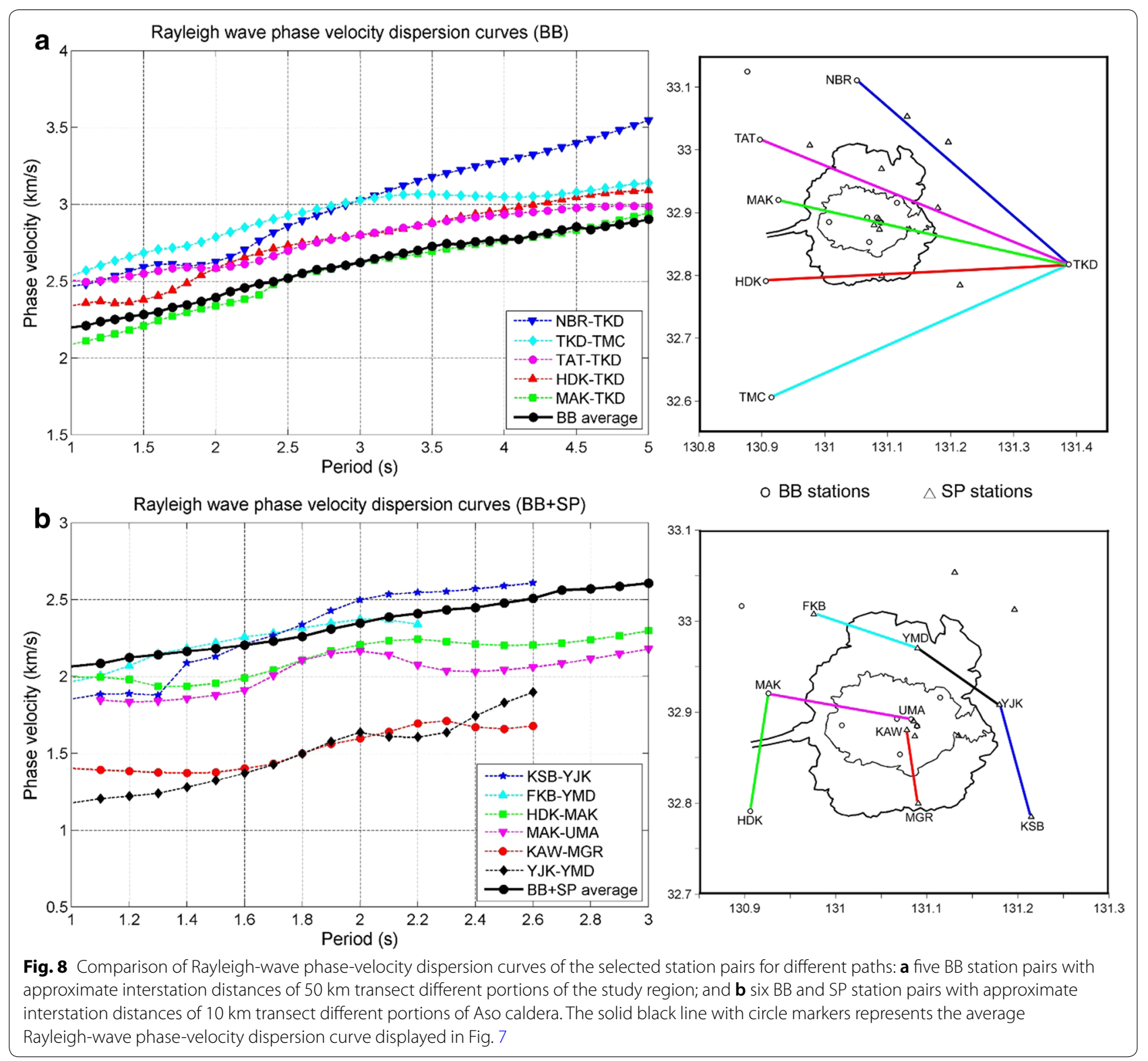

the northern part of the caldera; the east was characterized by low velocity and the west by high velocity. Figure $14 \mathrm{~d}$ depicts the profile transecting the post-caldera central cones near Kusasenrigahama, the center of the post-caldera central cones, in a longitudinal orientation. The most prominent features in Figs. $14 \mathrm{c}$ and d were the sharp contrasts in velocity (H3 and L3) between the surface and the depth of $6 \mathrm{~km}$.

Additionally, Figs. 14a and d display one low-velocity anomaly $(V \mathrm{~s}<2 \mathrm{~km} / \mathrm{s}$, L4) located at a depth of
1-2 $\mathrm{km}$ beneath a local high velocity in the southwest of Kusasenrigahama. This low-velocity anomaly extended from L4 to the surface and was located approximately at Kusasenrigahama.

We further integrated all derived 1-D Vs structures into 3-D Vs structures to gain a better understanding of the $V$ s distributions. Figure 15 presents two views of cross sections from the south and north, and the $V$ s structures are similar to that present in Fig. 14. 


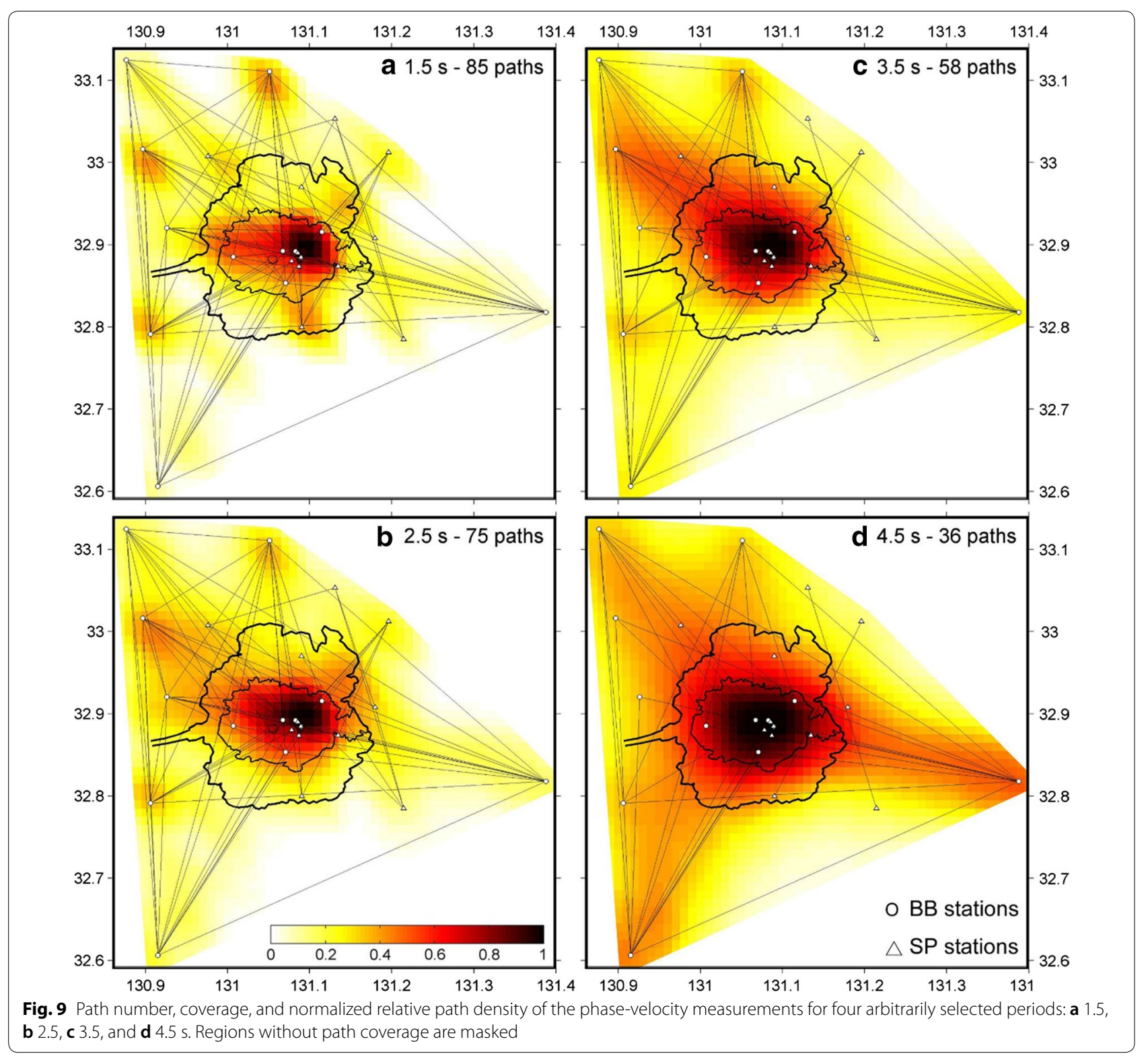

\section{Discussion}

\section{The structures beneath the post-caldera central cones}

We analyzed ambient seismic noise signals to assess the $V$ s structures (Figs. 14 and 15) at a depth of $6 \mathrm{~km}$ beneath Aso caldera and in its vicinity. The post-caldera central cones are characterized by high velocities (H1) from the surface to a depth of $1 \mathrm{~km}$, except surrounding Kusasenrigahama; low velocity prevails at the surface and extends to shallow low-velocity anomalies at depths of $1-2.5 \mathrm{~km}$ (L1 and L4). High velocities (H2) are dominant below $3 \mathrm{~km}$; nevertheless, here low-velocity anomalies (L2 and L3) still exist beneath the post-caldera central cones.
By summarizing the results and interpretations of other studies (e.g., Sudo 1991; Kaneshima et al. 1996; Sudo and Kong 2001; Tsutsui and Sudo 2004; Kanda et al. 2008; Hata et al. 2016; Sofyan et al. 2016; Nobile et al. 2017), we learnt that $V$ s structures are generally correlated with hydrothermal fluid or magma distributions. High velocities might correspond to rocks with high density or low temperature, porosity, and permeability, which in turn could indicate the presence of consolidated igneous rock. By comparison, low velocities might correspond to rocks with low density or high temperature, porosity, and permeability, similar to hydrothermal reservoirs containing 


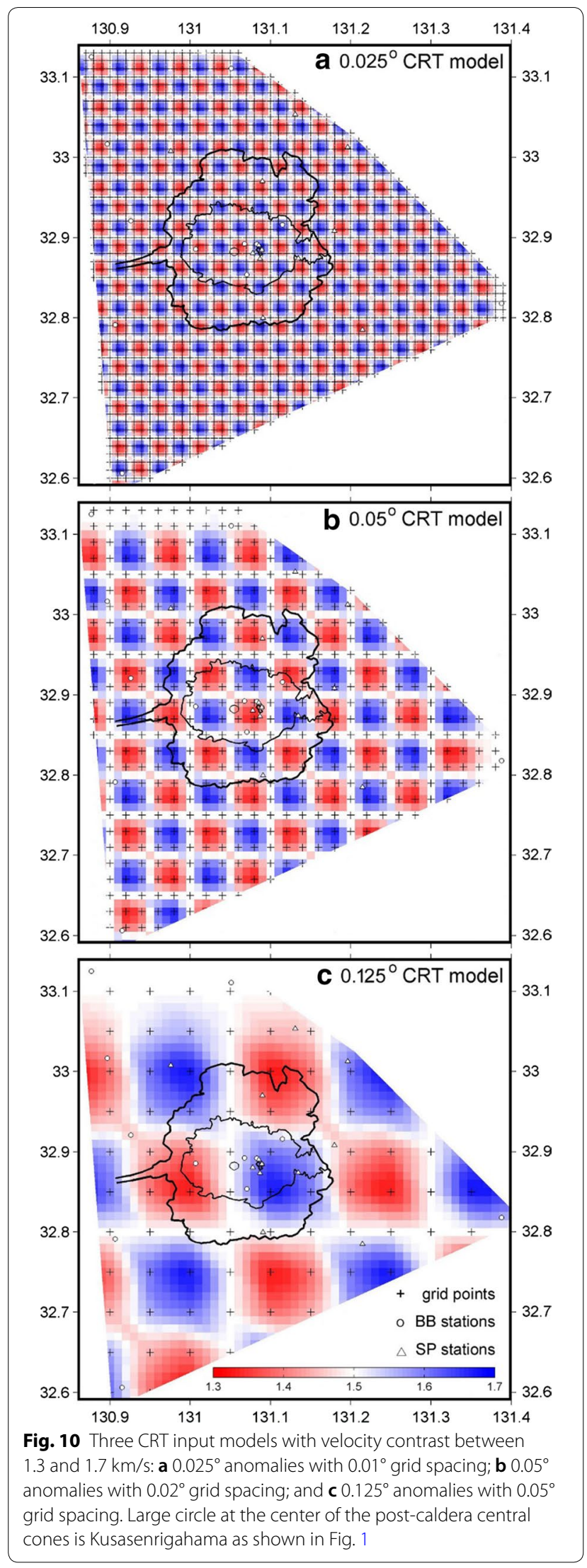

fluids or pathways allowing the easy migration of volcanic gases, fluids, and magma to the surface. Therefore, $\mathrm{H} 1$ and $\mathrm{H} 2$ correspond to the presence of consolidated igneous rock; meanwhile, L1 and L4 can be assumed to be hydrothermal reservoirs correlated to the surface geothermal activity observed on the first crater of Nakadake and on the southwestern flanks of the post-caldera central cones.

Some studies have hypothesized LPTs at a depth of $1-1.5 \mathrm{~km}$ beneath the Nakadake crater generated by hydrothermal reservoirs, which have their own correlation with occasional phreatic eruptions (Kaneshima et al. 1996; Kawakatsu et al. 2000; Legrand et al. 2000). However, these results were obtained by studies using seismic arrays with small apertures, concentrated near the Nakadake crater. Hence, such studies were limited to detecting hydrothermal reservoirs in the crater area at depths of $1-1.5 \mathrm{~km}$. By contrast, we utilized more seismic stations across a larger area and achieved higher lateral resolution under the post-caldera central cones. Consequently, we detected shallow low-velocity zones beneath the post-caldera central cones at depths of $1-2.5 \mathrm{~km}$, which have been here suggested to be hydrothermal reservoirs.

In a seismic attenuation study, Sudo (1991) identified low-velocity materials located beneath the center of Aso caldera at a depth of approximately 6-9 km. Sudo and Kong (2001) specified that the lowest velocities $(V \mathrm{~s}=2 \mathrm{~km} / \mathrm{s})$ indicated a magma chamber-roughly spherical in shape, centered at a depth of $6 \mathrm{~km}$, and flattened at $10 \mathrm{~km}$-that was located between Kishimadake, Eboshidake, and Nakadake. Nobile et al. (2017) used long-term InSAR (interferometric synthetic aperture radar) observations to suggest the existence of a magmatic source at a depth of 4-5 $\mathrm{km}$ beneath the center of Aso caldera. Hence, the low velocities (L2) located at depths of 5-6 km beneath the post-caldera central cones could indicate the top of magma reservoirs.

Other studies have observed cracks and passages exhibiting low velocities that could conceivably connect between the surfaces and volcanic reservoirs (Yamamoto et al. 1999; Tsutsui and Sudo 2004). The low-velocity belts (L3) we detected at depths between 2.5 and $5 \mathrm{~km}$ are likely pathways allowing the passage of hydrothermal fluids, volcanic gases, and melting magma from deeper crust to the surface. Tsutsui and Sudo (2004) reported the presence of seismic reflection voids (i.e., regions with high temperature, high seismic attenuation, and low velocity) surrounding the crater area and the locations of these voids were comparable with those of our low-velocity anomalies. They also inferred the presence of a reflector horizon at a depth of $2 \mathrm{~km}$, similar to our $V \mathrm{~s}=3 \mathrm{~km} / \mathrm{s}$ 


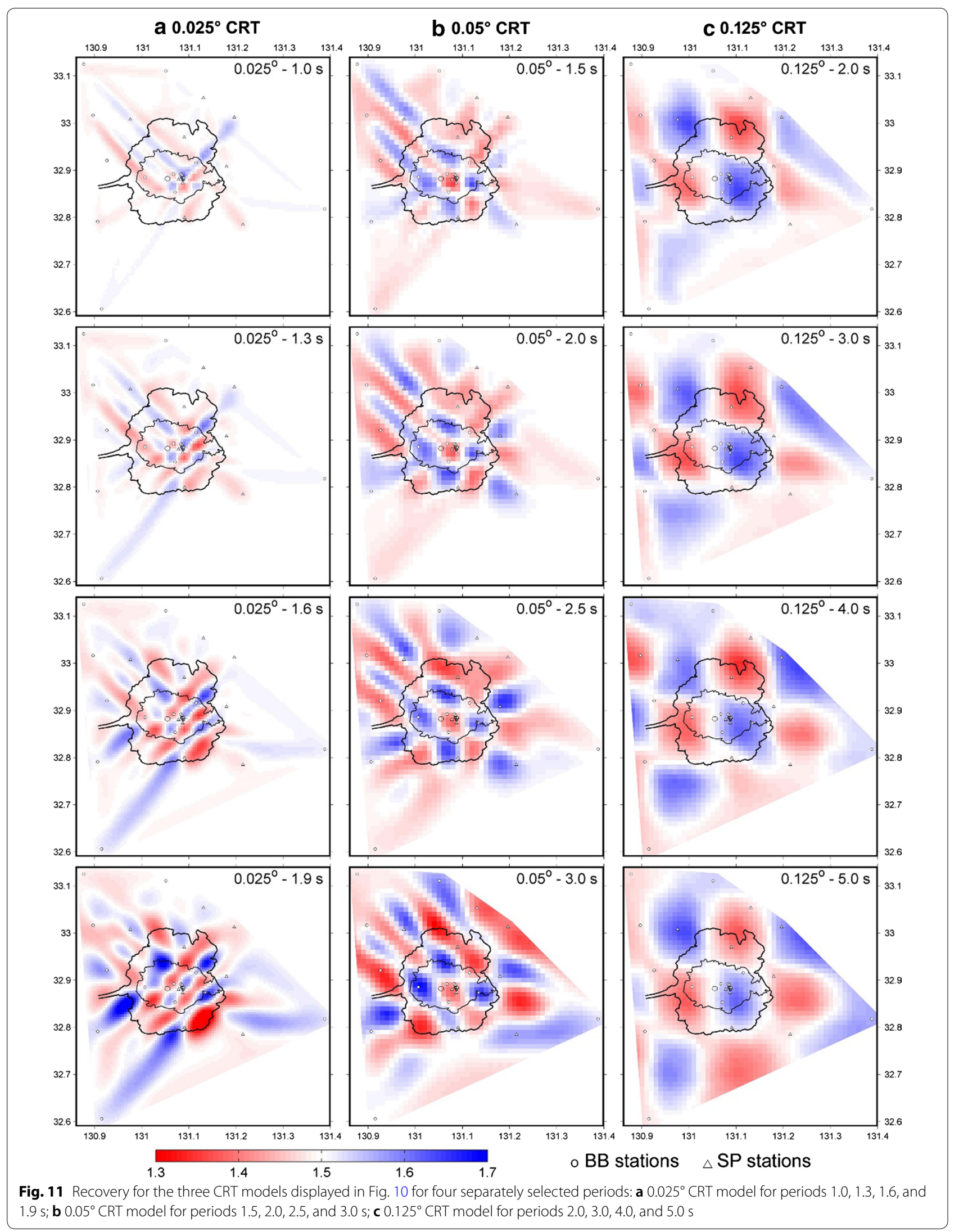




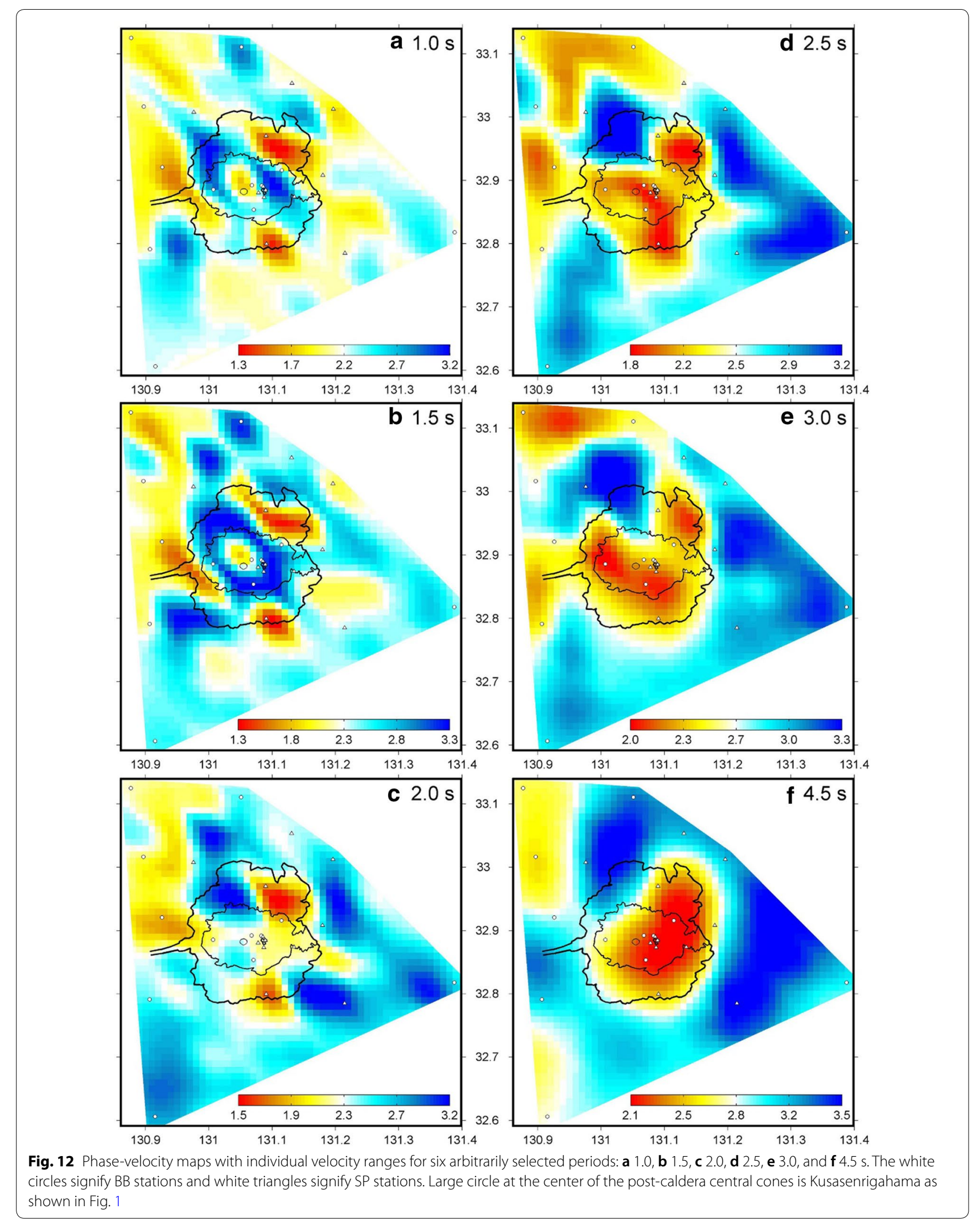




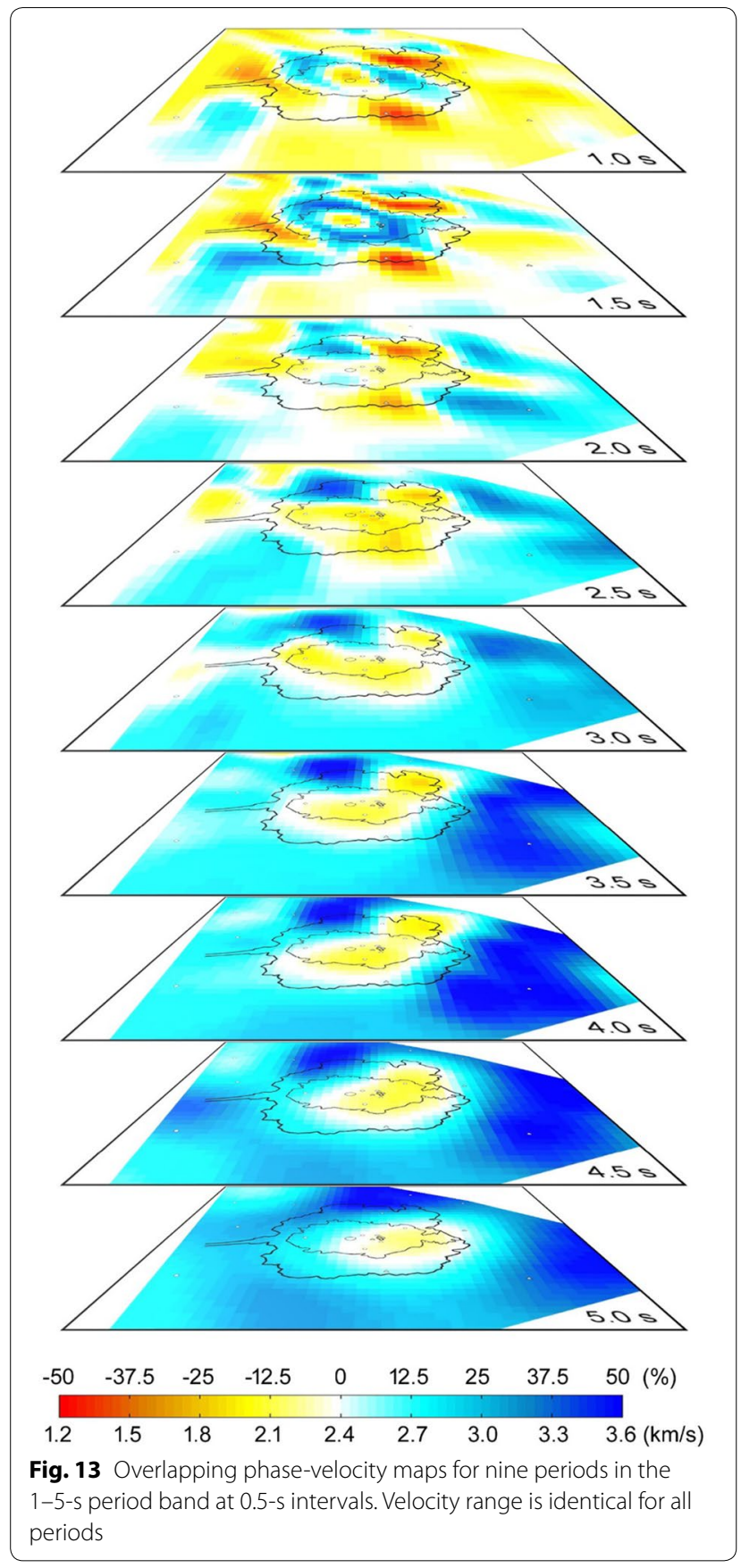

interface; this could possibly be the top surface of preAso volcanic or basement rock.

\section{Other parts of Aso caldera}

The northern part of the caldera exhibits noteworthy variations in lateral velocity, with low velocities predominately distributed in the east and high velocities in the west. The lateral velocity variation we discovered in the northern part of the caldera has also been observed in MT experiments. Kagiyama et al. (2016) measured high conductivity in the surface layer, especially at the Uchinomaki hot spring area (Fig. 1a), which implied that the hydrothermal water supply originated in the deeper crust or Nakadake crater. Hata et al. (2016) also reported lateral discrepancies in electrical resistivity in the northern part of the caldera at a depth of approximately $2.0 \mathrm{~km}$, and an extremely low resistivity was predominant beneath Nakadake at various depths.

Another relatively thick low- $V \mathrm{~s}$ anomaly was situated alongside the west-northwest surface of Aso caldera. Sudo and Kong (2001) discerned low velocity at a depth of $3 \mathrm{~km}$ near the western caldera wall at Tateno Valley (Fig. 1a). The Oita-Kumamoto Tectonic Line is an important NE-SW structure across central Kyushu passing through Aso and other active volcanoes (e.g., Kamata and Kodama 1999; Kusumoto 2016). However, the OitaKumamoto Tectonic Line in our Vs structures is less conspicuous than in those of other studies (e.g., Komazawa 1995; Tsutsui and Sudo 2004), presumably because of the lower $\left(0.125^{\circ}\right)$ lateral resolution for our $V$ s structures along the Oita-Kumamoto Tectonic Line.

Regarding Bouguer anomalies, high gravity was more dominant outside of the caldera, whereas low gravity prevailed, with a steep gradient, inside of Aso caldera (Komazawa 1995). In contrast to our velocity distributions, high $V \mathrm{~s}$ (high density) anomalies characterized the outside of Aso caldera. Low- $V \mathrm{~s}$ (low density) anomalies were predominant inside of Aso caldera, especially under the post-caldera central cones, which act as volcanic conduits for hydrothermal and magmatic systems (i.e., low resistivity or high conductivity).

\section{Summary of discussion}

After imaging shallow volcanic reservoirs and pathways beneath Aso caldera, we confirm the agreement with other studies and further understand the structure of the volcano. Low- $V \mathrm{~s}$ anomalies are predominant under the post-caldera central cones, which act as volcanic conduits connect magma chambers located at depths of 5-6 km with shallow hydrothermal reservoirs located at depths of 1-2.5 km. By contrast, high $V \mathrm{~s}$ anomalies characterize the first kilometer of the crust beneath post-caldera central cones, i.e., above the shallow hydrothermal reservoirs. When volcanic activity increases and energy cannot be released immediately, this could result in gradual accumulation of pressure and occasionally occurrence of phreatic or phreatomagmatic eruptions. Besides, 


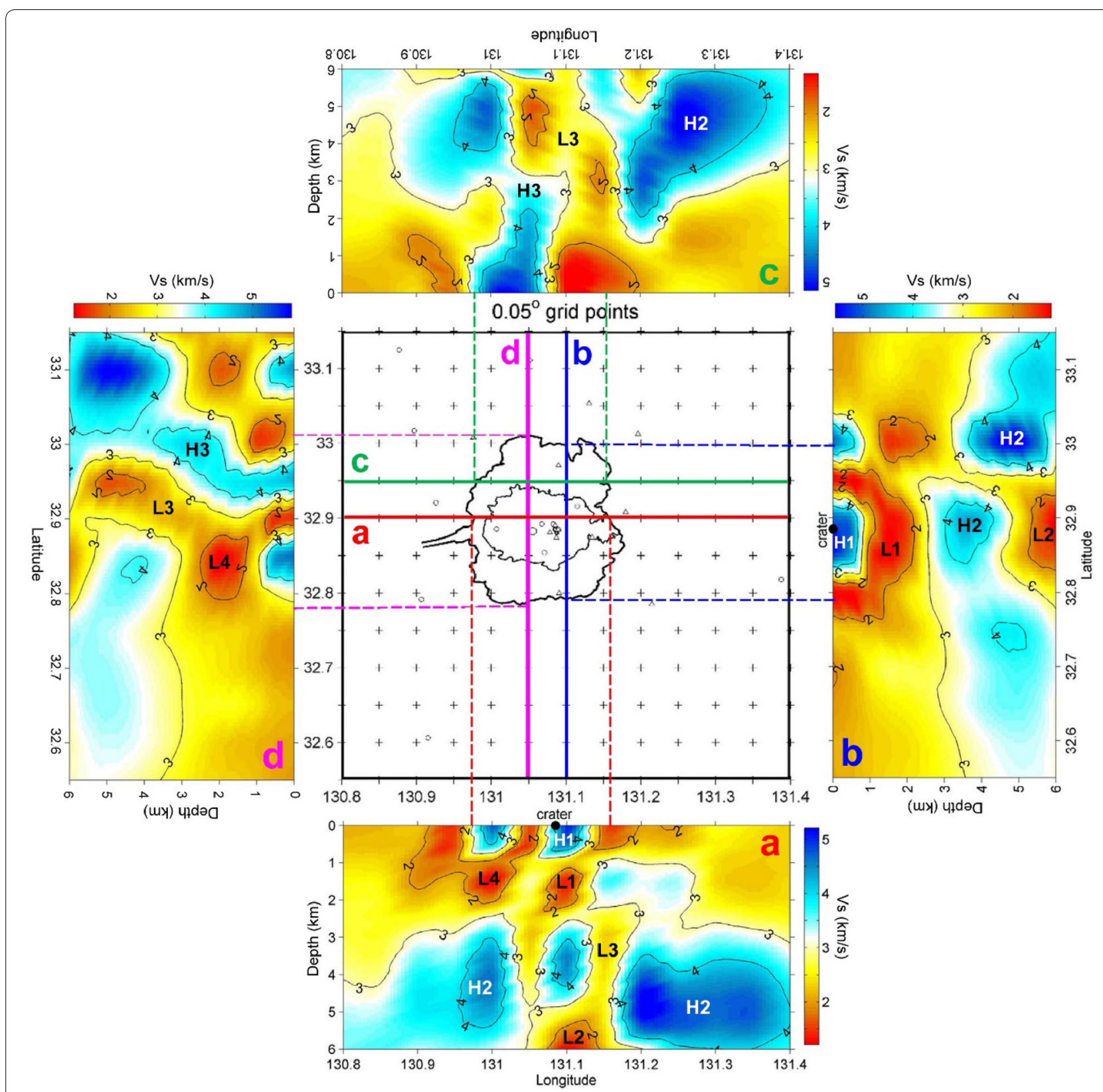

Fig. 14 Four Vs profiles transect Aso caldera at depth of $6 \mathrm{~km}: \mathbf{a} 32.9^{\circ} \mathrm{N}$ across the Nakadake crater; $\mathbf{b} 131.1^{\circ} \mathrm{E}$ across the Nakadake crater; $\mathbf{c} 32.95^{\circ} \mathrm{N}$ across the northern part of the caldera; and $\mathbf{d} 131.05^{\circ} \mathrm{E}$ across post-caldera central cones near Kusasenrigahama. Dashed lines mark the profile boundaries of Aso caldera, and crosses mark the locations of $0.05^{\circ}$ grid points. $\mathrm{H} 1-\mathrm{H} 3$ and $\mathrm{L} 1-\mathrm{L} 4$ are the identified velocity anomalies

our $V \mathrm{~s}$ structures are generally comparable with electrical resistivity and gravity studies. That is, low velocities correspond to rocks with low density and resistivity as hydrothermal reservoirs or pathways containing volcanic fluids; instead, high velocities correspond to rocks with high density and resistivity as consolidated igneous rock. Further investigations might be needed to understand the lateral velocity variation in the northern part of the caldera. 

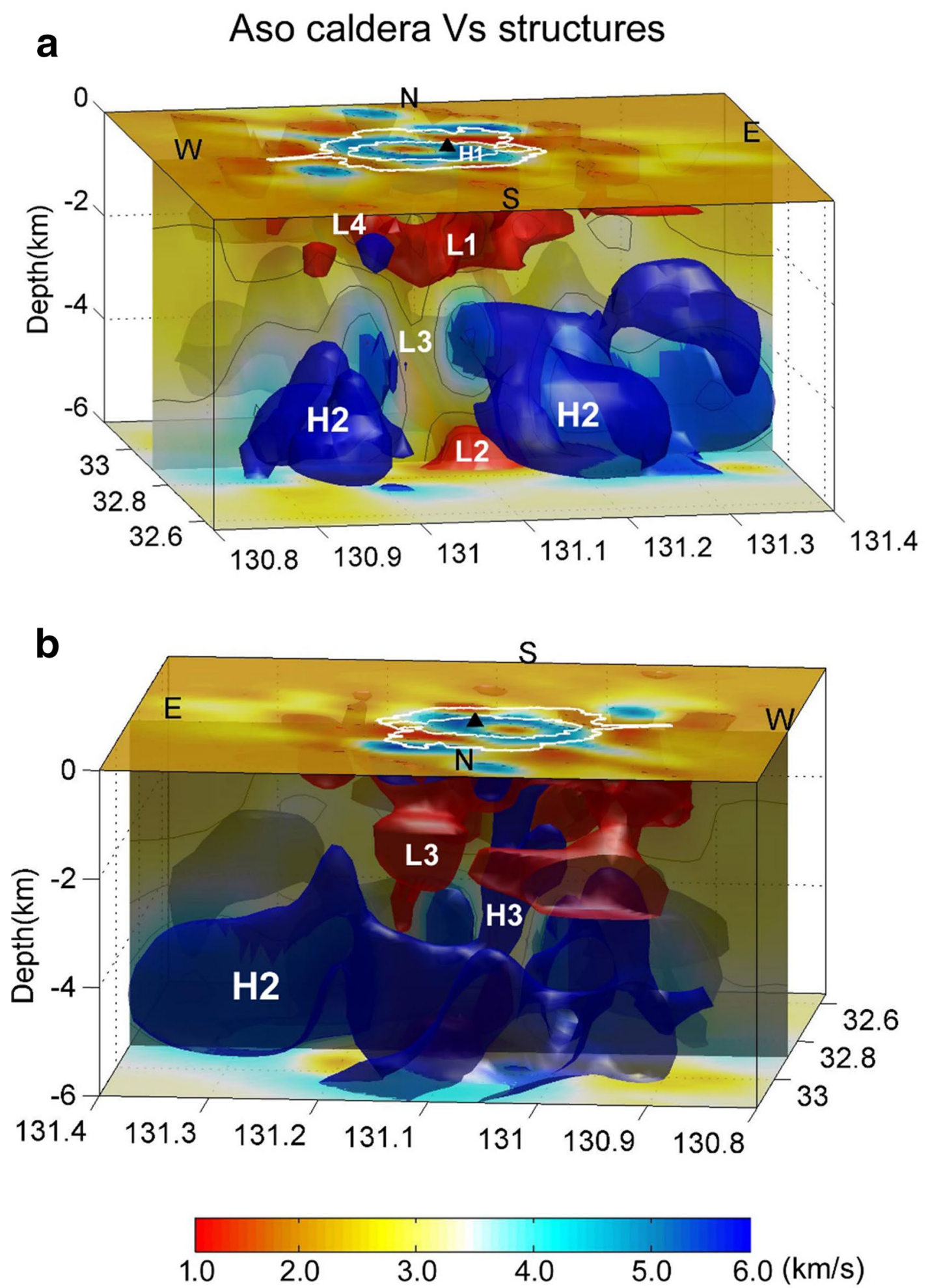

Fig. 15 Two 3-D Vs structures located $6 \mathrm{~km}$ beneath Aso caldera. Cross sections provide perspectives from the a south and $\mathbf{b}$ north. The black triangle marks the location of the Nakadake crater. Red shapes indicate $V s=2.0 \mathrm{~km} / \mathrm{s}$ and blue shapes indicate $V s=4.0 \mathrm{~km} / \mathrm{s}$. H1-H3 and L1-L4 are the same velocity anomalies as displayed in Fig. 14 


\section{Conclusions}

Using analyses of ambient seismic noise signals, we derived crustal $V$ s structures at a depth of $6 \mathrm{~km}$ beneath Aso caldera. The seismic data set spanned a time period of approximately 4 years and was primarily collected from the network operated by the AVL, with some additional data from stations belonging to the NIED and JMA. In total, 25 seismic stations, 13 of which had BB and 12 of which had SP seismometers, were included in this network, with interstation distances of approximately 1-2 km near the Nakadake crater. The daily CCFs of the BB and SP station pairs were calculated separately with a $100-\mathrm{s}$ lag time in the $1-10-\mathrm{s}$ and $0.2-5$-s period bands for the BB and SP station pairs, respectively. The stacked monthly CCFs were used to obtain the Rayleighwave phase-velocity dispersion curves, and 1-5-s phasevelocity maps were constructed with $0.05^{\circ}$ grid spacing. The 6-km-deep crustal $V$ s structures beneath Aso caldera were then derived.

The post-caldera central cones are characterized by high velocities from the surface to a depth of $1 \mathrm{~km}$. In the center of the post-caldera central cones, approximately at Kusasenrigahama, low velocities prevail at the surface and extend to major anomalies at depths of 1-2.5 km. These low-velocity anomalies can be assumed to be shallow hydrothermal reservoirs that might be related to surface geothermal activity; it is possible that these reservoirs are replenished by precipitation and hydrographic networks within the caldera or through pathways connecting it to deeper earth. The prevalence of high velocities below $3 \mathrm{~km}$ can be considered to correspond to consolidated igneous rock. However, the low velocities identified at depths of 5-6 km beneath the post-caldera central cones might indicate the tops of magma chambers. The low-velocity belts situated at $2.5-5 \mathrm{~km}$ depths are likely pathways for the transfer of hydrothermal fluids, volcanic gases, or melting magma to the surface. The northern part of the caldera exhibits substantial lateral velocity variations, that is, low velocity predominates in the east and high velocity predominates in the west. Additionally, low $V$ s anomalies are identified adjacent to the western and northwestern surface of Aso caldera.

\footnotetext{
Abbreviations

AVL: Aso Volcanological Laboratory; BB: broadband; CCF: cross-correlation function; CRT: checkerboard resolution test; $\mathrm{d}_{H}$ : horizontal interstation distance; $d_{L}$ : linear distance; $d_{V}$ : vertical elevation difference; InSAR: interferometric synthetic aperture radar; JMA: Japan Meteorological Agency; LPT: Iongperiod tremor; MT: magnetotelluric; NIED: National Research Institute for Earth Science and Disaster Resilience; SAC: Seismic Analysis Code; SP: short period; TDEGF: time-domain empirical Green's function; VLPD: very long period displacements; Vp: P-wave velocity; Vs: S-wave velocity.
}

\section{Authors' contributions}

YCH analyzed the seismic data set and drafted the manuscript. TO maintained and compiled the AVL seismic data. TO and TK discussed the results and commented on the manuscript. SY and HI maintained the AVL seismic stations. All authors read and approved the final manuscript.

\section{Author details \\ ${ }^{1}$ National Center for Research on Earthquake Engineering, National Applied Research Laboratories, No. 200, Section 3 Xinhai Rd, Taipei 10668, Taiwan. \\ ${ }^{2}$ Aso Volcanological Laboratory, Institute for Geothermal Sciences, Graduate School of Science, Kyoto University, 3028 Sakanashi, Ichinomiyamachi, Aso, Kumamoto 869-2911, Japan. ${ }^{3}$ Aso Volcano Museum, 1930-1, Akamizu, Aso, Kumamoto 869-2232, Japan.}

\section{Acknowledgements}

The authors would like to thank the editor Dr. Valerio Acocella, associate editors and two anonymous reviewers for their constructive comments to help us improve the manuscript significantly. We would like to thank Drs. ChengHorng Lin, Teh-Ru Alex Song, Che-Min Lin, and Wen-Tzong Liang for their constructive comments. Most of the codes for ambient seismic noise analysis and tomography were developed by Huajian Yao, University of Science and Technology of China. We used the broadband seismic data of the National Research Institute for Earth Science and Disaster Resilience, Japan and the Japan Meteorological Agency. We used Generic Mapping Tools (Wessel and Smith 1998) to generate some figures.

\section{Competing interests}

The authors declare that they have no competing interests.

\section{Availability of data and materials}

Please contact author for data requests. The data of NIED broadband seismograph network (F-net) used in this article are available at the Data Management Center (http://www.fnet.bosai.go.jp/top.php?LANG=en).

\section{Funding}

This research was partly supported by Ministry of Education, Culture, Sports, Science and Technology of Japan, under its Earthquake and Volcano Hazards Observation and Research Program.

\section{Publisher's Note}

Springer Nature remains neutral with regard to jurisdictional claims in published maps and institutional affiliations.

Received: 30 March 2018 Accepted: 20 October 2018

Published online: 29 October 2018

\section{References}

Abe Y, Ohkura T, Shibutani T, Hirahara K, Kato M (2010) Crustal structure beneath Aso caldera, Southwest Japan, as derived from receiver function analysis. J Volcanol Geotherm Res 195:1-12. https://doi.org/10.1016/j. jvolgeores.2010.05.011

Abe Y, Ohkura T, Shibutani T, Hirahara K, Yoshikawa S, Inoue H (2017) Lowvelocity zones in the crust beneath Aso caldera, Kyushu, Japan, derived from receiver function analyses. J Geophys Res 122(3):2013-2033. https:// doi.org/10.1002/2016JB013686

Bensen GD, Ritzwoller MH, Shapiro NM (2008) Broadband ambient noise surface wave tomography across the United States. J Geophys Res 113(B5):B05306. https://doi.org/10.1029/2007JB005248

Brenguier F, Shapiro NM, Campillo M, Nercessian A, Ferrazzini V (2007) 3-D surface wave tomography of the Piton de la Fournaise volcano using seismic noise correlations. Geophys Res Lett 34(2):L02305. https://doi. org/10.1029/2006GL028586

Cupillard P, Capdeville Y (2010) On the amplitude of surface waves obtained by noise correlation and the capability to recover the attenuation: a numerical approach. Geophys J Int 181(3):1687-1700. https://doi. org/10.1111/j.1365-246X.2010.04586.x 
Cupillard P, Stehly L, Romanowicz B (2011) The one-bit noise correlation: a theory based on the concepts of coherent and incoherent noise. Geophys J Int 184(3):1397-1414. https://doi.org/10.1111/j.1365-246X.2010.04923.x

De Plaen RSM, Lecocq T, Caudron C, Ferrazzini V, Francis O (2016) Single-station monitoring of volcanoes using seismic ambient noise. Geophys Res Lett 43(16):8511-8518. https://doi.org/10.1002/2016GL070078

Escudero CR, Bandy WL (2017) Ambient seismic noise tomography of the Colima Volcano Complex. Bull Volcanol 79(2):13. https://doi.org/10.1007/ s00445-016-1096-2

Fujii J, Nakajima T, Kamata H (2001) Paleomagnetic directions of the Aso pyroclastic-flow and the Aso-4 co-ignimbrite ash-fall deposits in Japan. Earth Planets Space 53:1137-1150. https://doi.org/10.1186/BF03352409

Goldstein P, Dodge D, Firpo M, Minner L (2003) SAC2000: signal processing and analysis tools for seismologists and engineers. In: Lee WHK, Kanamori $\mathrm{H}$, Jennings PC, Kisslinger C (eds) Invited contribution to the IASPEI international handbook of earthquake and engineering seismology. Academic Press, London

Goutorbe B, de Oliveira Coelho DL, Drouet S (2015) Rayleigh wave group velocities at periods of $6-23 \mathrm{~s}$ across Brazil from ambient noise tomography. Geophys J Int 203(2):869-882. https://doi.org/10.1093/gji/ggv343

Hata M, Takakura S, Matsushima N, Hashimoto T, Utsugi M (2016) Crustal magma pathway beneath Aso caldera inferred from three-dimensional electrical resistivity structure. Geophys Res Lett 43:10720-10727. https:// doi.org/10.1002/2016GL070315

Herrmann RB (1987) Computer programs in seismology, user's manual, IV. St. Louis University, St. Louis

Herrmann RB (2013) Computer programs in seismology: an evolving tool for instruction and research. Seismol Res Lett 84(6):1081-1088. https://doi. org/10.1785/0220110096

Huang Y-C, Yao H, Huang B-S, van der Hilst RD, Wen K-L, Huang W-G, Chen C-H (2010) Phase velocity variation at periods $0.5-3$ seconds in the Taipei Basin of Taiwan from correlation of ambient seismic noise. Bull Seismol Soc Am 100(5A):2250-2263. https://doi.org/10.1785/0120090319

Huang Y-C, Yao H, Wu FT, Liang W-T, Huang B-S, Lin C-H, Wen K-L (2014) Crustal and upper mantle S-wave velocity structures across the Taiwan Strait from ambient seismic noise and teleseismic Rayleigh wave analyses. J Asian Earth Sci 81:38-52. https://doi.org/10.1016/j.jseaes.2013.11.023

Huang Y-C, Lin C-H, Kagiyama T (2017) Shallow crustal velocities and volcanism suggested from ambient noise studies using a dense broadband seismic network in the Tatun Volcano Group of Taiwan. JVolcanol Geotherm Res 341:6-20. https://doi.org/10.1016/j.jvolgeores.2017.05.016

Ikebe S, Watanabe K, Miyabuchi Y (2008) The sequence and style of the 1988-1995 eruptions of Nakadake Aso volcano, Kyushu, Japan. Bull Volcanol Soc Japan 53(1):15-33. https://doi.org/10.18940/kazan.53.1_15 (in Japanese with English abstract)

Ishii K, Hayashi Y, Shimbori T (2018) Using Himawari-8, estimation of $\mathrm{SO}_{2}$ cloud altitude at Aso volcano eruption, on October 8, 2016. Earth Planets Space 70:19. https://doi.org/10.1186/s40623-018-0793-9

Japan Meteorological Agency (2013) National catalogue of the active volcanoes in Japan (the fourth edition, English version). Japan Meteorological Agency, Tokyo. http://www.data.jma.go.jp/svd/vois/data/tokyo/STOCK souran_eng/menu.htm. Accessed 26 July 2017

Kagiyama T, Yoshikawa S, Utsugi M (2016) Conductivity distribution of the surface layer around Aso caldera. Ann Disas Prev Res Inst, Kyoto Univ 59B:84-91 (in Japanese with English abstract)

Kamata H, Kodama K (1999) Volcanic history and tectonics of the Southwest Japan Arc. Island Arc 8:393-403. https://doi.org/10.104 6/j.1440-1738.1999.00241.x

Kanamori H, Anderson DL (1977) Importance of physical dispersion in surface wave and free oscillation problems: review. Rev Geophys 15(1):105-112. https://doi.org/10.1029/RG015i001p00105

Kanda W, Tanaka Y, Utsugi M, Takakura S, Hashimoto T, Inoue H (2008) A preparation zone for volcanic explosions beneath Naka-dake crater, Aso volcano, as inferred from magnetotelluric surveys. J Volcanol Geotherm Res 178:32-45. https://doi.org/10.1016/j.jvolgeores.2008.01.022

Kaneshima S, Kawakatsu H, Matsubayashi H, Sudo Y, Tsutsui T, Ohminato T, Ito H, Uhira K, Yamasato H, Oikawa J, Takeo M, lidaka T (1996) Mechanism of phreatic eruptions at Aso volcano inferred from near-field broadband seismic observations. Science 273:642-645. https://doi.org/10.1126/scien ce. 273.5275 .642
Kao H, Behr Y, Currie CA, Hyndman R, Townend J, Lin F-C, Ritzwoller MH, Shan SJ, He J (2013) Ambient seismic noise tomography of Canada and adjacent regions: part I. Crustal structures. J Geophys Res 118(11):5865-5887. https://doi.org/10.1002/2013JB010535

Kawakatsu H, Ohminato T, Ito H (1994) 10 s-period volcanic tremors observed over a wide area in southwestern Japan. Geophys Res Lett 21(18):19631966. https://doi.org/10.1029/94GL01683

Kawakatsu H, Kaneshima S, Matsubayashi H, Ohminato T, Sudo Y, Tsutsui T, Uhira K, Yamasato H, Ito H, Legrand D (2000) Aso94: Aso seismic observation with broadband instruments. J Volcanol Geotherm Res 101:129-154. https://doi.org/10.1016/S0377-0273(00)00166-9

Komazawa M (1995) Gravimetric analysis of Aso volcano and its interpretation. J Geodetic Soc Jpn 41(1):17-45. https://doi.org/10.11366/sokuchi195 4.41 .17

Kusumoto S (2016) Dip distribution of Oita-Kumamoto Tectonic Line located in central Kyushu, Japan, estimated by eigenvectors of gravity gradient tensor. Earth Planets Space 68:153. https://doi.org/10.1186/s4062 3-016-0529-7

Larose E, Derode A, Campillo M, Fink M (2004) Imaging from one-bit correlations of wideband diffuse wave fields. J Appl Phys 95(12):8393-8399. https://doi.org/10.1063/1.1739529

Legrand D, Kaneshima S, Kawakatsu H (2000) Moment tensor analysis of near-field broadband waveforms observed at Aso Volcano, Japan. J Volcanol Geotherm Res 101:155-169. https://doi.org/10.1016/S0377 $-0273(00) 00167-0$

Lin F-C, Ritzwoller MH, Townend J, Bannister S, Savage MK (2007) Ambient noise Rayleigh wave tomography of New Zealand. Geophys J Int 170(2):649-666. https://doi.org/10.1111/j.1365-246X.2007.03414.x

Lin F-C, Moschetti MP, Ritzwoller MH (2008) Surface wave tomography of the western United States from ambient seismic noise: Rayleigh and Love wave phase velocity maps. Geophys J Int 173(1):281-298. https://doi. org/10.1111/j.1365-246X.2008.03720.x

Ma Y, Clayton RW, Tsai VC, Zhan Z (2013) Locating a scatterer in the active volcanic area of Southern Peru from ambient noise cross-correlation. Geophys J Int 192(3):1332-1341. https://doi.org/10.1093/gji/ggs 103

Machida H, Arai F (1983) Extensive ash falls in and around the Sea of Japan from large late quaternary eruptions. J Volcanol Geotherm Res 18(1):151164. https://doi.org/10.1016/0377-0273(83)90007-0

Miyabuchi Y (2009) A 90,000-year tephrostratigraphic framework of Aso Volcano, Japan. Sediment Geol 220(3-4):169-189. https://doi.org/10.1016/j. sedgeo.2009.04.018

Miyabuchi Y (2011) Post-caldera explosive activity inferred from improved 67-30 ka tephrostratigraphy at Aso Volcano, Japan. J Volcanol Geotherm Res 205(3-4):94-113. https://doi.org/10.1016/j.jvolgeores.2011.05.004

Miyabuchi Y, Hoshizumi H, Takada H, Watanabe K, Xu S (2003) Pumice-fall deposits from Aso volcano during the past 90,000 years, southwestern Japan. Bull Volcanol Soc Japan 48(2):195-214. https://doi.org/10.18940/ kazan.48.2_195 (in Japanese with English abstract)

Miyabuchi Y, lizuka Y, Hara C, Yokoo A, Ohkura T (2018) The September 14, 2015 phreatomagmatic eruption of Nakadake first crater, Aso Volcano, Japan: eruption sequence inferred from ballistic, pyroclastic density current and fallout deposits. J Volcanol Geotherm Res 351:41-56. https://doi. org/10.1016/j.jvolgeores.2017.12.009

Nagaoka Y, Nishida K, Aoki Y, Takeo M, Ohminato T (2012) Seismic imaging of magma chamber beneath an active volcano. Earth Planet Sci Lett 333-334:1-8. https://doi.org/10.1016/j.epsl.2012.03.034

Nishida K, Montagner JP, Kawakatsu H (2009) Global surface wave tomography using seismic hum. Science 326(5942):112. https://doi.org/10.1126/scien ce. 1176389

Nobile A, Acocella V, Ruch J, Aoki Y, Borgstrom S, Siniscalchi V, Geshi N (2017) Steady subsidence of a repeatedly erupting caldera through InSAR observations: Aso, Japan. Bull Volcanol 79(5):32. https://doi.org/10.1007/s0044 5-017-1112-1

Ono K, Watanabe K (1985) Geological map of Aso Volcano 1:50,000. In: Geological map of volcanoes, no. 4. Geological Survey of Japan. (in Japanese with English abstract)

Red Relief Image Map (2018) Asia Air Survey Co., Ltd., Tokyo. https://www.rrim. $\mathrm{jp} /$. Accessed 30 Mar 2018

Roux P, Sabra KG, Kuperman WA, Roux A (2005) Ambient noise cross correlation in free space: theoretical approach. J Acoust Soc Am 117(1):79-84 
Sabra KG, Gerstoft P, Roux P, Kuperman WA, Fehler MC (2005a) Extracting timedomain Green's function estimates from ambient seismic noise. Geophys Res Lett 32(3):L03310. https://doi.org/10.1029/2004GL021862

Sabra KG, Gerstoft P, Roux P, Kuperman WA, Fehler MC (2005b) Surface wave tomography from microseisms in Southern California. Geophys Res Lett 32(14):L14311. https://doi.org/10.1029/2005GL023155

Sabra KG, Roux P, Gerstoft P, Kuperman WA, Fehler MC (2006) Extracting coherent coda arrivals from cross-correlations of long period seismic waves during the Mount St. Helens 2004 eruption. Geophys Res Lett 33(6):L06313. https://doi.org/10.1029/2005GL025563

SAC Manual (2017) Incorporated research institutions for seismology, Washington, DC. http://ds.iris.edu/files/sac-manual/. Accessed 20 Sept 2017

Saygin E, Kennett BLN (2010) Ambient seismic noise tomography of Australian continent. Tectonophysics 481(1-4):116-125. https://doi.org/10.1016/j. tecto.2008.11.013

Sens-Schönfelder C (2008) Synchronizing seismic networks with ambient noise. Geophys J Int 174(3):966-970. https://doi.org/10.1111/j.1365246X.2008.03842.x

Sens-Schönfelder C, Wegler U (2006) Passive image interferometry and seasonal variations of seismic velocities at Merapi Volcano, Indonesia. Geophys Res Lett 33(21):L21302. https://doi.org/10.1029/2006GL027797

Shapiro NM, Campillo M (2004) Emergence of broadband Rayleigh waves from correlations of the ambient seismic noise. Geophys Res Lett 31(7):L07614. https://doi.org/10.1029/2004GL019491

Shapiro NM, Campillo M, Stehly L, Ritzwoller MH (2005) High-resolution surface-wave tomography from ambient seismic noise. Science 307:1615-1618. https://doi.org/10.1126/science.1108339

Sofyan Y, Nishijima J, Fujimitsu Y, Yoshikawa S, Kagiyama T, Ohkura T (2016) The oscillation model of hydrothermal dynamics beneath Aso volcano, southwest Japan after small eruption on May 2011: a new understanding model using repeated absolute and relative gravity measurement. J Volcanol Geotherm Res 310:172-185. https://doi.org/10.1016/j.jvolgeores .2015.12.012

Stehly L, Campillo M, Shapiro NM (2006) A study of the seismic noise from its long-range correlation properties. J Geophys Res 111 (B10):B10306. https ://doi.org/10.1029/2005JB004237

Stehly L, Campillo M, Shapiro NM (2007) Traveltime measurements from noise correlation: stability and detection of instrumental time-shifts. Geophys J Int 171(1):223-230. https://doi.org/10.1111/j.1365-246X.2007.03492.x

Sudo Y (1991) An attenuating structure beneath the Aso caldera determined from the propagation of seismic waves. Bull Volcanol 53:99-111. https:// doi.org/10.1007/BF00265415

Sudo Y (2001) The character of volcanic activity at Aso volcano: an open system volcano. Chikyu Mon 23:545-550 (in Japanese)
Sudo Y, Kong LSL (2001) Three-dimensional seismic velocity structure beneath Aso volcano, Kyushu, Japan. Bull Volcanol 63:326-344. https://doi. org/10.1007/s004450100145

Tamura J, Okada T (2016) Ambient noise tomography in the Naruko/Onikobe volcanic area, NE Japan: implications for geofluids and seismic activity. Earth Planets Space 68:5. https://doi.org/10.1186/s40623-016-0380-x

Tsutsui T, Sudo Y (2004) Seismic reflectors beneath the central cones of Aso Volcano, Kyushu, Japan. J Volcanol Geotherm Res 131(1-2):33-58. https:// doi.org/10.1016/S0377-0273(03)00315-9

Tsutsui T, Sudo Y, Mori T, Katsumata K, Tanaka S, Oikawa J, Tomatsu T, Matsuwo N, Matsushima T, Miyamachi H, Nishi K, Fujiwara Y, Hiramatsu H (2003) 3-D seismic velocity structure beneath the edifice of central cones of Aso Volcano. Bull Volcanol Soc Japan 48(3):293-307. https://doi.org/10.18940/ kazan.48.3_293 (in Japanese with English abstract)

Weaver RL (2005) Information from seismic noise. Science 307:1568-1569. https://doi.org/10.1126/science.1109834

Wessel P, Smith WHF (1998) New, improved version of the generic mapping tools released. EOS Trans AGU 79:579

WIN system (2017) Earthquake research institute, the University of Tokyo, Tokyo. (in Japanese). http://eoc.eri.u-tokyo.ac.jp/WIN/. Accessed 19 Sept 2017

Yamamoto M, Kawakatsu H, Kaneshima S, Mori T, Tsutsui T, Sudo Y, Morita Y (1999) Detection of a crack-like conduit beneath the active crater at Aso volcano Japan. Geophys Res Lett 26(24):3677-3680. https://doi. org/10.1029/1999GL005395

Yang Y, Ritzwoller MH, Levshin AL, Shapiro NM (2007) Ambient noise Rayleigh wave tomography across Europe. Geophys J Int 168(1):259-274. https:// doi.org/10.1111/j.1365-246X.2006.03203.x

Yao H, Campman X, de Hoop MV, van der Hilst RD (2009) Estimation of surface wave Green's functions from correlation of direct waves, coda waves, and ambient noise in SE Tibet. Phys Earth Planet Inter 177(1-2):1-11. https:// doi.org/10.1016/j.pepi.2009.07.002

Yao H, van der Hilst RD, de Hoop MV (2006) Surface-wave array tomography in SE Tibet from ambient seismic noise and two-station analysis-I. Phase velocity maps. Geophys J Int 166(2):732-744. https://doi.org/10.1111/ j.1365-246X.2006.03028.X

Zheng S, Sun X, Song X, Yang Y, Ritzwoller MH (2008) Surface wave tomography of China from ambient seismic noise correlation. Geochem Geophys Geosyst 9(5):Q05020. https://doi.org/10.1029/2008GC001981

\section{Submit your manuscript to a SpringerOpen ${ }^{\odot}$ journal and benefit from:}

- Convenient online submission

- Rigorous peer review

- Open access: articles freely available online

- High visibility within the field

- Retaining the copyright to your article

Submit your next manuscript at $\boldsymbol{\nabla}$ springeropen.com 